\title{
LEVEL II SCOUR ANALYSIS FOR BRIDGE 17 (NEWHTH00200017) on TOWN HIGHWAY 20, crossing LITTLE OTTER CREEK, NEW HAVEN, VERMONT
}

Open-File Report 98-015

Prepared in cooperation with

VERMONT AGENCY OF TRANSPORTATION

and

FEDERAL HIGHWAY ADMINISTRATION

U.S. Department of the Interior

U.S. Geological Survey

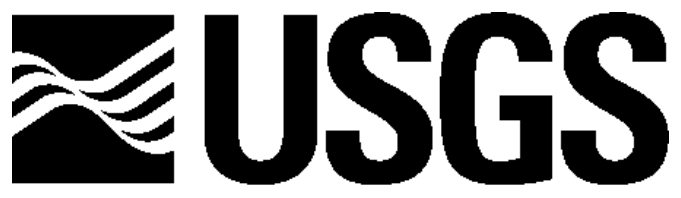

science for a changing world 


\section{LEVEL II SCOUR ANALYSIS FOR BRIDGE 17 (NEWHTH00200017) on TOWN HIGHWAY 20, crossing LITTLE OTTER CREEK, NEW HAVEN, VERMONT By EMILY C. WILD and RONDA L. BURNS}

U.S. Geological Survey Open-File Report 98-015

Prepared in cooperation with

VERMONT AGENCY OF TRANSPORTATION and

FEDERAL HIGHWAY ADMINISTRATION 


\title{
U.S. DEPARTMENT OF THE INTERIOR BRUCE BABBITT, Secretary
}

\author{
U.S. GEOLOGICAL SURVEY \\ Mark Schaefer, Acting Director
}

For additional information write to:

District Chief

U.S. Geological Survey 361 Commerce Way

Pembroke, NH 03275-3718
Copies of this report may be purchased from:

U.S. Geological Survey

Branch of Information Services

Open-File Reports Unit

Box 25286

Denver, CO 80225-0286 


\section{CONTENTS}

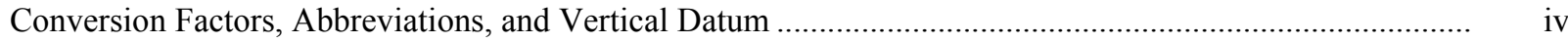

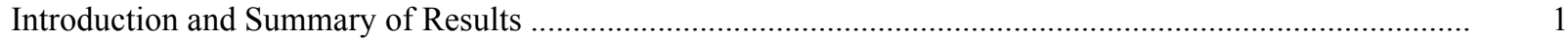

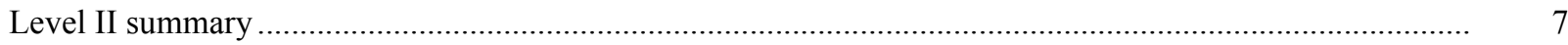

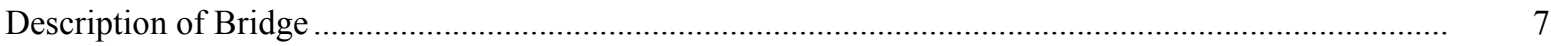

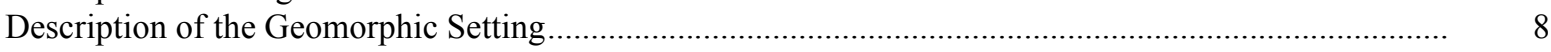

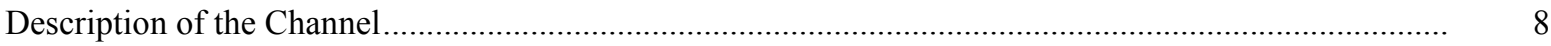

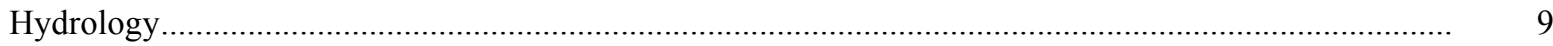

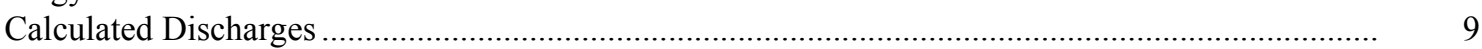

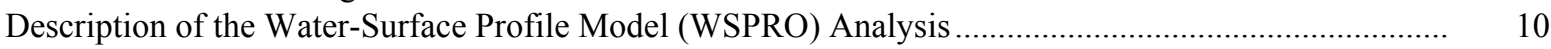

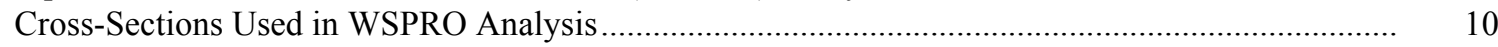

Data and Assumptions Used in WSPRO Model ........................................................................ 11

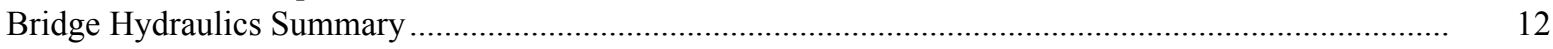

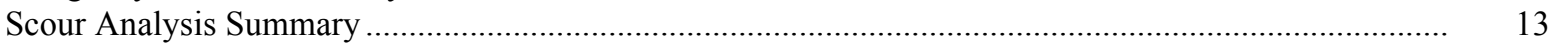

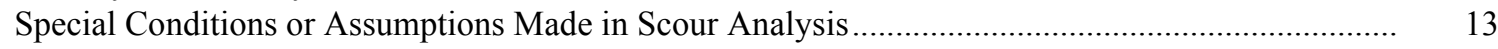

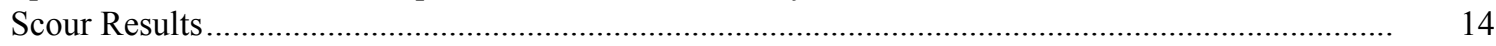

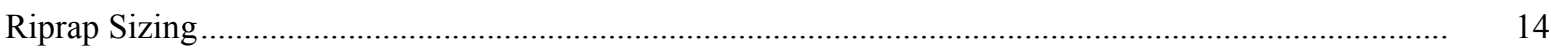

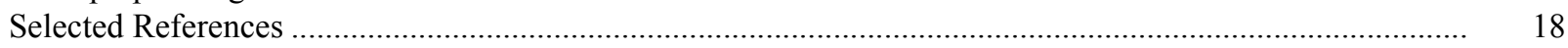

Appendices:

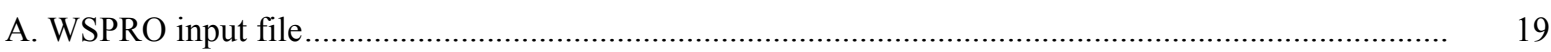

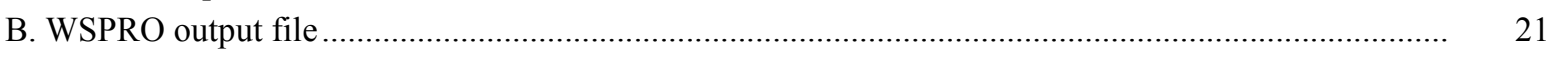

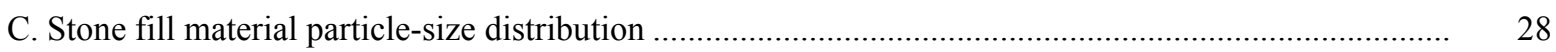

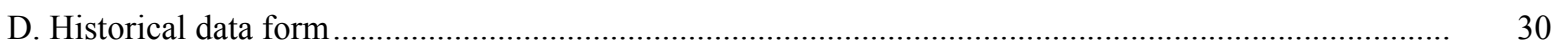

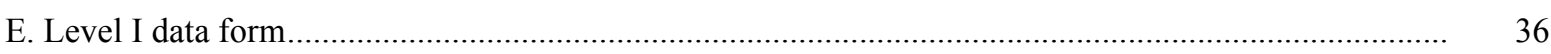

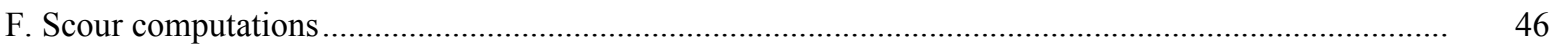

\section{FIGURES}

1. Map showing location of study area on USGS 1:24,000 scale map

2. Map showing location of study area on Vermont Agency of Transportation town highway map

3. Structure NEWHTH00200017 viewed from upstream (June 11, 1996)

4

4. Downstream channel viewed from structure NEWHTH00200017 (June 11, 1996).............................. 5

5. Upstream channel viewed from structure NEWHTH00200017 (June 11, 1996)...................................

6. Structure NEWHTH00200017 viewed from downstream (June 11, 1996).

7. Water-surface profiles for the 100- and 500-year discharges at structure

NEWHTH00200017 on Town Highway 20, crossing Little Otter Creek,

New Haven, Vermont

8. Scour elevations for the 100- and 500-year discharges at structure

NEWHTH00200017 on Town Highway 20, crossing Little Otter Creek,

New Haven, Vermont.

\section{TABLES}

1. Remaining footing/pile depth at abutments for the 100-year discharge at structure

NEWHTH00200017 on Town Highway 20, crossing Little Otter Creek,

New Haven, Vermont

2. Remaining footing/pile depth at abutments for the 500-year discharge at structure

NEWHTH00200017 on Town Highway 20, crossing Little Otter Creek,

New Haven, Vermont 


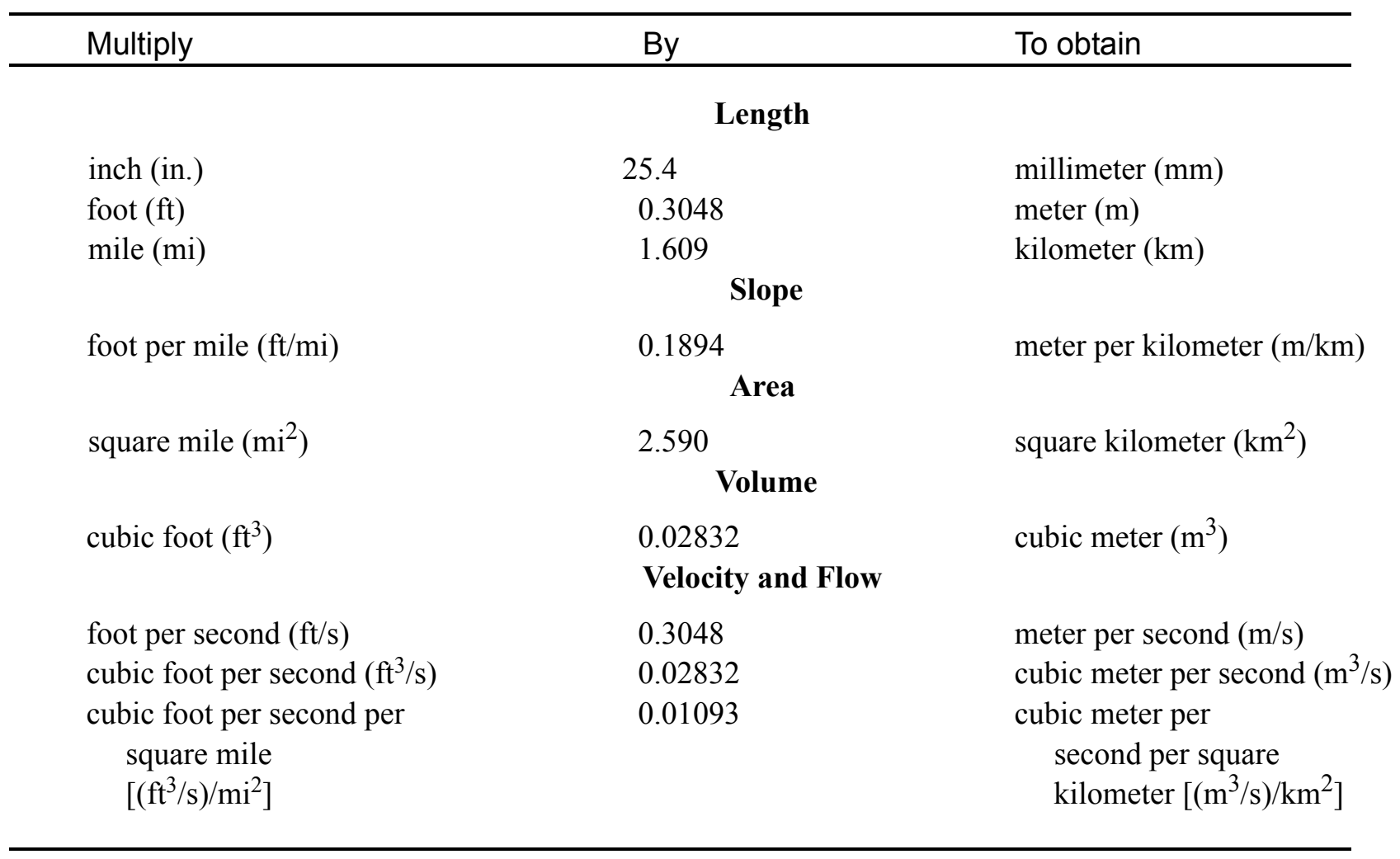

\section{OTHER ABBREVIATIONS}

$\begin{array}{lrlr}\mathrm{BF} & \text { bank full } & \text { LWW } & \text { left wingwall } \\ \mathrm{cfs} & \text { cubic feet per second } & \text { Max } & \text { Maximum } \\ \mathrm{D}_{50} & \text { median diameter of bed material } & \text { MC } & \text { main channel } \\ \mathrm{DS} & \text { downstream } & \text { RAB } & \text { right abutment } \\ \text { elev. } & \text { elevation } & \text { RABUT } & \text { face of right abutment } \\ \mathrm{f} / \mathrm{p} & \text { flood plain } & \text { RB } & \text { right bank } \\ \mathrm{ft}^{2} & \text { square feet } & \text { ROB } & \text { right overbank } \\ \mathrm{ft} / \mathrm{ft} & \text { feet per foot } & \text { RWW } & \text { right wingwall } \\ \mathrm{FHWA} & \text { Federal Highway Administration } & \text { TH } & \text { town highway } \\ \text { JCT } & \text { junction } & \text { UB } & \text { under bridge } \\ \text { LAB } & \text { left abutment } & \text { US } & \text { upstream } \\ \text { LABUT } & \text { face of left abutment } & \text { USGS } & \text { United States Geological Survey } \\ \text { LB } & \text { left bank } & \text { VTAOT } & \text { Vermont Agency of Transportation } \\ \text { LOB } & \text { left overbank } & \text { WSPRO } & \text { water-surface profile model } \\ & & \text { yr } & \text { year }\end{array}$

In this report, the words "right" and "left" refer to directions that would be reported by an observer facing downstream. Sea level: In this report, "sea level" refers to the National Geodetic Vertical Datum of 1929-- a geodetic datum derived from a general adjustment of the first-order level nets of the United States and Canada, formerly called Sea Level Datum of 1929.

In the appendices, the above abbreviations may be combined. For example, USLB would represent upstream left bank. 


\title{
LEVEL II SCOUR ANALYSIS FOR BRIDGE 17 (NEWHTH00200017) ON TOWN HIGHWAY 20, CROSSING LITTLE OTTER CREEK, NEW HAVEN, VERMONT
}

\author{
By Emily C. Wild and Ronda L. Burns
}

\section{INTRODUCTION AND SUMMARY OF RESULTS}

This report provides the results of a detailed Level II analysis of scour potential at structure NEWHTH00200017 on Town Highway 20 crossing Little Otter Creek, New Haven, Vermont (figures 1-8). A Level II study is a basic engineering analysis of the site, including a quantitative analysis of stream stability and scour (U.S. Department of Transportation, 1993). Results of a Level I scour investigation also are included in appendix $E$ of this report. A Level I investigation provides a qualitative geomorphic characterization of the study site. Information on the bridge, gleaned from Vermont Agency of Transportation (VTAOT) files, was compiled prior to conducting Level I and Level II analyses and is found in appendix D.

The site is in the Champlain section of the St. Lawrence Valley physiographic province in west-central Vermont. The $10.8-\mathrm{mi}^{2}$ drainage area is in a predominantly rural and wetland basin. In the vicinity of the study site, the surface cover is shrubland on the downstream right overbank. The surface cover of the downstream left overbank, the upstream right overbank and the upstream left overbank is wetland and pasture.

In the study area, Little Otter Creek has a meandering channel with a slope of approximately $0.0007 \mathrm{ft} / \mathrm{ft}$, an average channel top width of $97 \mathrm{ft}$ and an average bank height of $5 \mathrm{ft}$. The channel bed material ranges from silt and clay to cobble. Medium sized silt and clay is the channel material upstream of the approach cross-section and downstream of the exit cross-section. The median grain size (D50) of the silt and clay channel bed material is $1.52 \mathrm{~mm}(0.005 \mathrm{ft})$, which was used for contraction and abutment scour computations. From the approach cross-section, under the bridge, and to the exit crosssection, stone fill is the channel bed material. The median grain size $\left(\mathrm{D}_{50}\right)$ of the stone fill channel bed material is $95.7 \mathrm{~mm}(0.314 \mathrm{ft})$. The stone fill median grain size was used solely for armoring computations. The geomorphic assessment at the time of the Level I and Level II site visit on June 11, 1996, indicated that the reach was stable. 
The Town Highway 20 crossing of Little Otter Creek is a 32-ft-long, two-lane bridge consisting of a 28-ft steel-beam span (Vermont Agency of Transportation, written communication, December 15, 1995). The opening length of the structure parallel to the bridge face is $24.9 \mathrm{ft}$. The bridge is supported by almost vertical, concrete abutments. The channel is skewed approximately 15 degrees to the opening while the opening-skew-toroadway is zero degrees.

The scour countermeasures at the site consisted of type-1 stone fill (less than 12 inches diameter) along the left and right abutments, as well as along the upstream left and right banks. Type- 2 stone fill (less than 36 inches diameter) was present along the downstream right bank. Additional details describing conditions at the site are included in the Level II Summary and appendices D and E.

Scour depths and recommended rock rip-rap sizes were computed using the general guidelines described in Hydraulic Engineering Circular 18 (Richardson and Davis, 1995) for the 100- and 500-year discharges. In addition, the incipient roadway-overtopping discharge was determined and analyzed as another potential worst-case scour scenario. Total scour at a highway crossing is comprised of three components: 1) long-term streambed degradation; 2) contraction scour (due to accelerated flow caused by a reduction in flow area at a bridge) and; 3 ) local scour (caused by accelerated flow around piers and abutments). Total scour is the sum of the three components. Equations are available to compute depths for contraction and local scour and a summary of the results of these computations follows.

Contraction scour for all modelled flows ranged from 9.7 to $13.8 \mathrm{ft}$. The worst-case contraction scour occurred at the 500-year discharge. Left abutment scour ranged from 6.9 to $7.9 \mathrm{ft}$. Right abutment scour ranged from 10.5 to $11.8 \mathrm{ft}$. The worst-case left and right abutment scour occurred at the 500-year discharge. Additional information on scour depths and depths to armoring are included in the section titled "Scour Results". Scouredstreambed elevations, based on the calculated scour depths, are presented in tables 1 and 2. A cross-section of the scour computed at the bridge is presented in figure 8. Scour depths were calculated assuming an infinite depth of erosive material and a homogeneous particlesize distribution.

It is generally accepted that the Froehlich equation (abutment scour) gives "excessively conservative estimates of scour depths" (Richardson and Davis, 1995, p. 47). Usually, computed scour depths are evaluated in combination with other information including (but not limited to) historical performance during flood events, the geomorphic stability assessment, existing scour protection measures, and the results of the hydraulic analyses. Therefore, scour depths adopted by VTAOT may differ from the computed values documented herein. 


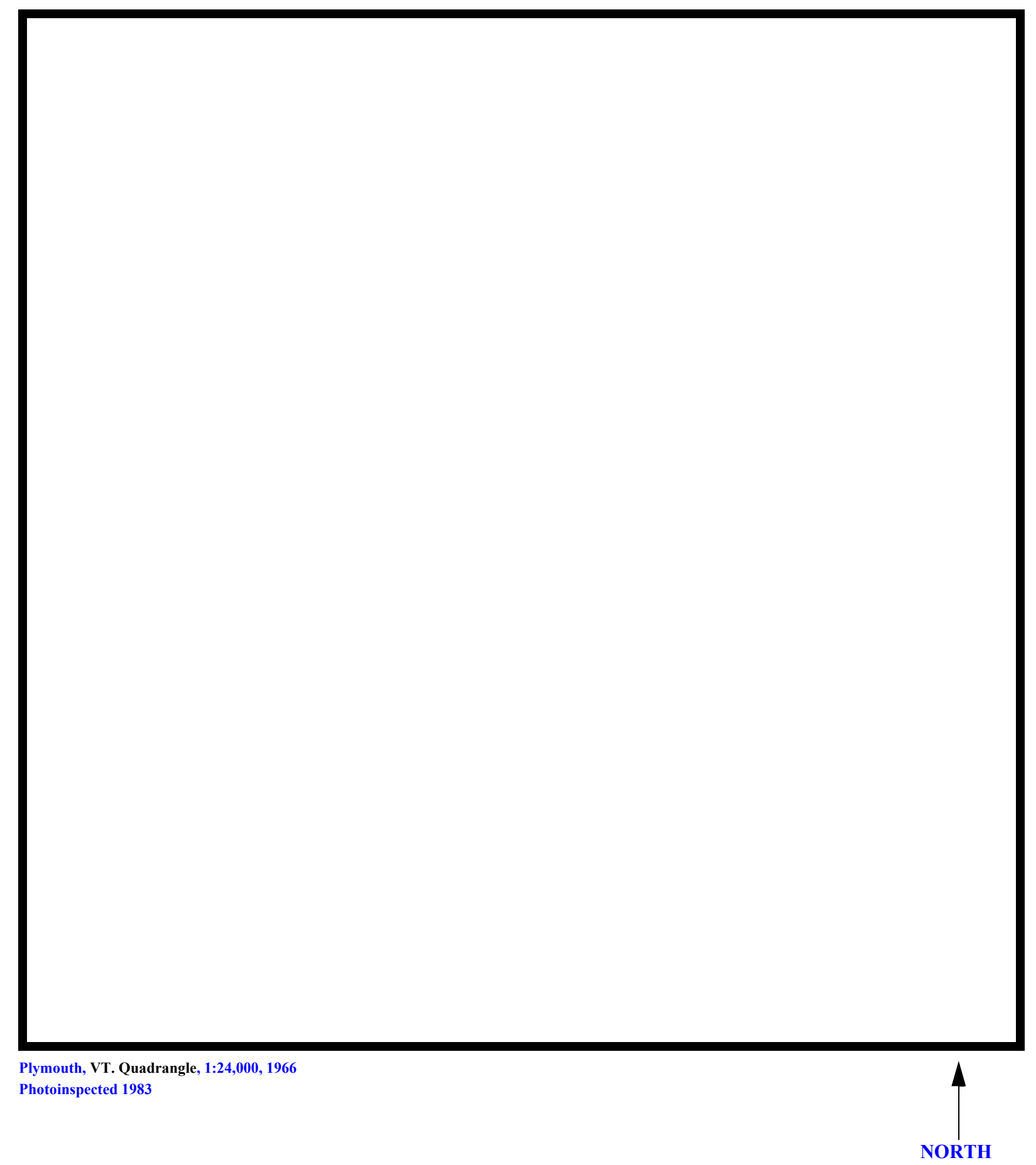

Figure 1. Location of study area on USGS 1:24,000 scale map. 
Figure 2. Location of study area on Vermont Agency of Transportation town highway map. 

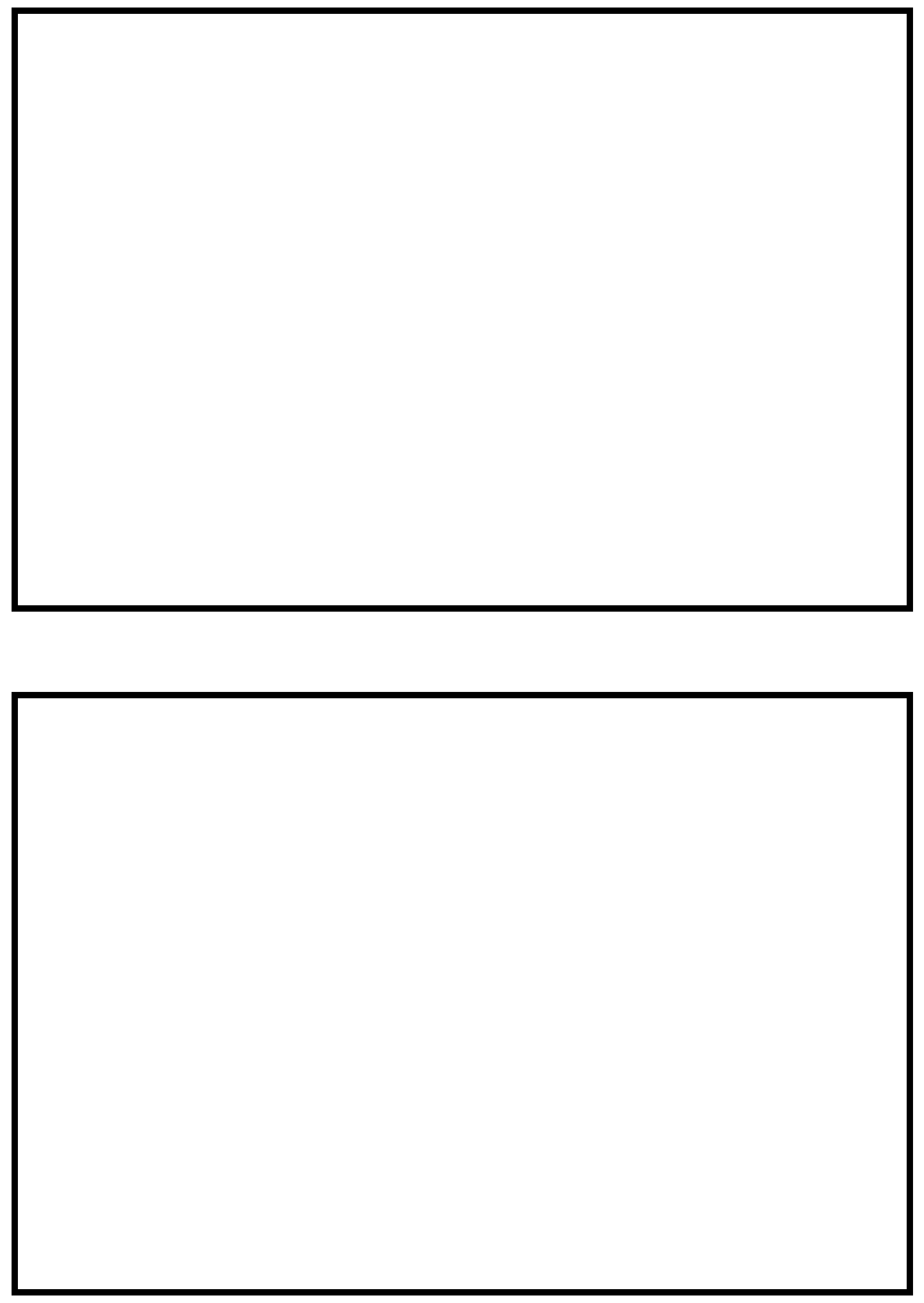

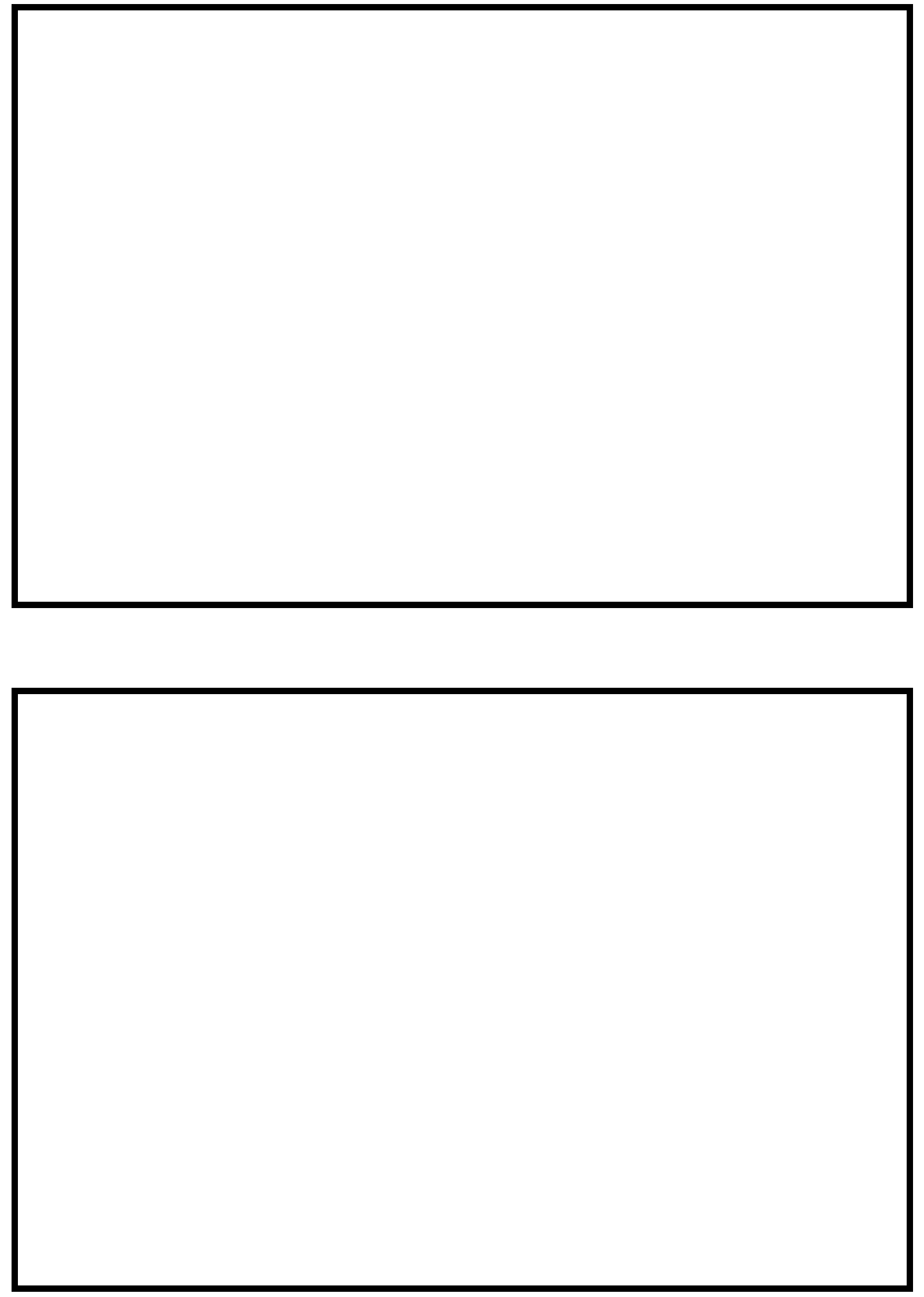


\section{LEVEL II SUMMARY}

\begin{tabular}{llllll} 
& Structure Number & NEWHTH00200017 & & \multicolumn{2}{c}{ Little Otter Creek } \\
Stream & & & & \\
County & Addison & Road & TH20 & District & 5
\end{tabular}

\section{Description of Bridge}

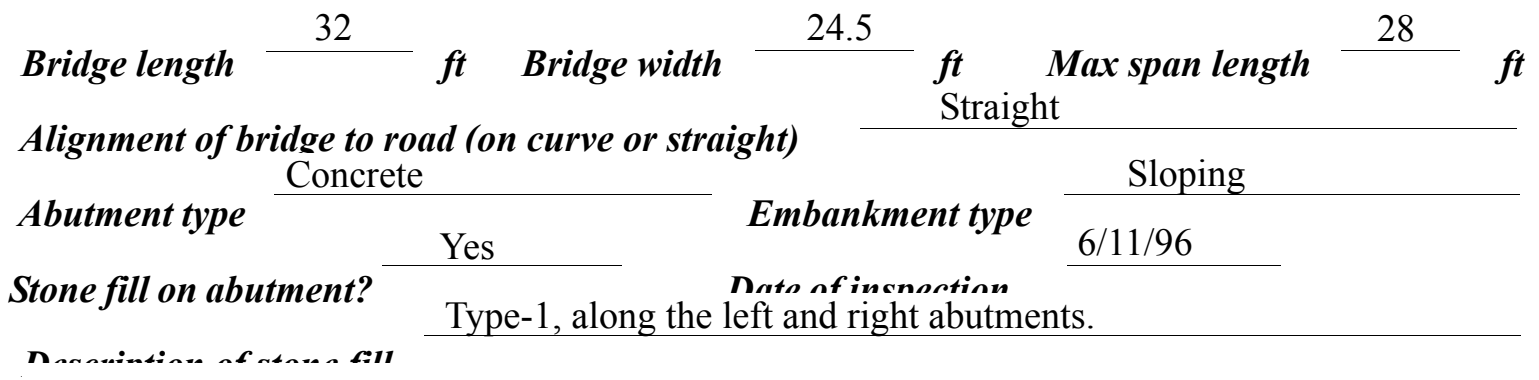

$\ldots \ldots . . . . .$.

Abutments and wingwalls are concrete.

Yes

Is bridge skewed to flood flow according to Yes 'survey? Angle

There is a moderate channel bend in the upstream and downstream reach.

Debris accumulation on bridge at time of Level I or Level II site visit:

\begin{tabular}{|c|c|c|c|}
\hline & $\begin{array}{c}\text { Date of insnortion } \\
6 / 11 / 96 \\
\end{array}$ & $\begin{array}{l}\text { Percent of almmust } \\
\text { blocked inortzontally }\end{array}$ & $\begin{array}{l}\text { Percent of al } \\
\text { blocked verticatty }\end{array}$ \\
\hline & $6 / 11 / 96$ & 0 & 0 \\
\hline & Low. & & \\
\hline
\end{tabular}

Potential for debris

None, (6/11/96).

Doscriho anv fontwros nonr or at tho hridos that mov affort flow, (includo ohsorvation doto) 


\section{Description of the Geomorphic Setting}

General topography The channel is located within a wide, slightly irregular flood plain with moderately sloped valley walls on both sides.

Geomorphic conditions at bridge site: downstream (DS), upstream (US)

Date of inspection $\quad 6 / 11 / 96$

DS left: $\quad$ Wide flood plain.

DS right: $\quad$ Narrow flood plain to a vertical quarry wall.

US left: $\quad$ Wide flood plain.

US right: $\quad$ Moderately sloped overbank

\section{Description of the Channel}

\begin{tabular}{|c|c|c|c|}
\hline \multirow[b]{2}{*}{ Average top width } & 97 & \multirow[b]{2}{*}{ Average depth } & \multirow[b]{2}{*}{ Silt/Bedrock } \\
\hline & Silt / Cobbles & & \\
\hline Predominant bed m & & Bank material & Meandering but \\
\hline
\end{tabular}

stable with semi-alluvial channei boundaries and a wide flood plain."

$6 / 11 / 96$

Vegetative co 1 Wetland and pasture

DS left: $\quad$ Shrubland

DS right: Wetland and pasture

US left: $\quad$ Wetland and pasture

US right: $\quad$ Yes

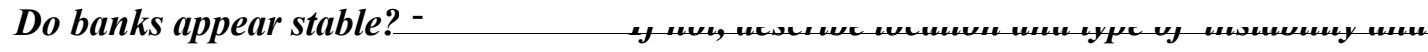

date of observation.

None, 6/11/96.

Describe any obstructions in channel and date of observation. 


\section{Hydrology}

Drainage area $\frac{10.8}{\boldsymbol{m i}^{2}}$

Percentage of drainage area in physiographic provinces: (approximate)

Physiographic province/section

St. Lawrence Valley/Champlain
Percent of drainage area 100

Is drainage area considered rural or urban? Rural _ Describe any significant urbanization:

Yes

Is there a USGS gage on the stream of interest? Little Otter Creek at Ferrisburg, VT USGS gage description 04282650

USGS gage number

57.1

Gage drainage area $\quad \mathrm{mi}^{2}$ No

Is there a lake/p However, there is a significant wetland area in the vicinity of Little Otter Creek.

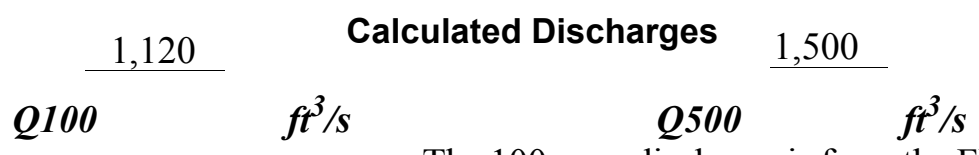

The 100-year discharge is from the FHWA empirical

relationship curye, and the 500-year discharge is based on values extrapolated from the FHWA empirical relationship curve (Benson, 1962; Johnson and Tasker, 1974; FHWA, 1983; Potter, 1957a\&b; Talbot, 1887). The FHWA curve values were within a range of curves of other empirical methods. 


\section{Description of the Water-Surface Profile Model (WSPRO) Analysis}

Datum for WSPRO analysis (USGS survey, sea level, VTAOT plans)

USGS survey

Datum tie between USGS survey and VTAOT plans

None

Description of reference marks used to determine USGS datum. $\quad$ RM1 is a chiseled X on top of the upstream end of the left abutment (elev. 499.66 feet, arbitrary survey datum). RM2 is a chiseled X on top of a boulder located 45 feet bankward of the right abutment and 35 feet downstream of the roadway (elev. 501.67 feet, arbitrary survey datum).

\section{Cross-Sections Used in WSPRO Analysis}

\begin{tabular}{cccl}
\hline${ }^{1}$ Cross-section & $\begin{array}{c}\text { Section } \\
\text { Reference } \\
\text { Distance } \\
\text { (SRD) } \text { in feet }\end{array}$ & $\begin{array}{c}{ }^{2} \text { Cross-section } \\
\text { development }\end{array}$ & \multicolumn{1}{c}{ Comments } \\
\hline EXITX & -23 & 1 & $\begin{array}{l}\text { Exit section } \\
\text { Downstream Full-valley } \\
\text { section (Templated from } \\
\text { FULLV }\end{array}$ \\
BRIDG & 0 & 2 & $\begin{array}{l}\text { BXidX) } \\
\text { RDWAY }\end{array}$ \\
APPRO & 13 & 1 & Road Grade section \\
\hline
\end{tabular}

${ }^{1}$ For location of cross-sections see plan-view sketch included with Level I field form, Appendix E. For more detail on how cross-sections were developed see WSPRO input file. 


\section{Data and Assumptions Used in WSPRO Model}

Hydraulic analyses of the reach were done by use of the Federal Highway Administration's WSPRO step-backwater computer program (Shearman and others, 1986, and Shearman, 1990). The analyses reported herein reflect conditions existing at the site at the time of the study. Furthermore, in the development of the model it was necessary to assume no accumulation of debris or ice at the site. Results of the hydraulic model are presented in the Bridge Hydraulic Summary, appendix B, and figure 7.

Channel roughness factors (Manning's "n”) used in the hydraulic model were estimated using field inspections at each cross section following the general guidelines described by Arcement and Schneider (1989). Final adjustments to the values were made during the modelling of the reach. Channel " $n$ " values for the reach ranged from 0.040 to 0.050 , and overbank " $\mathrm{n}$ " values ranged from 0.040 to 0.065 .

Normal depth at the exit section (EXITX) was assumed as the starting water surface. This depth was computed by use of the slope-conveyance method outlined in the user's manual for WSPRO (Shearman, 1990). The slope used was $0.0007 \mathrm{ft} / \mathrm{ft}$, which was estimated from the topographic map (U.S. Geological Survey, 1963).

The approach section (APPRO) was surveyed one bridge length upstream of the upstream face, as recommended by Shearman and others (1986). This location provides a consistent method for determining scour variables. 


\section{Bridge Hydraulics Summary}

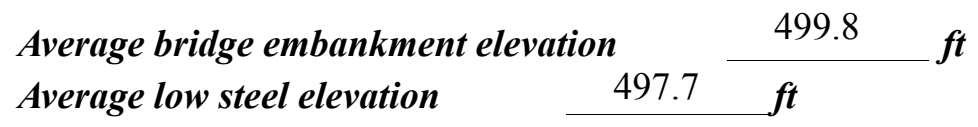

$$
\text { 100-year discharge } \quad 1,120 \quad \mathrm{ft}^{3} / \mathrm{s}
$$

Water-surface elevation in bridge opening $\quad 497.7 \quad f t$

Road overtopping? ___ Y Discharge over road __ 290 $\mathrm{ft}^{3} / \mathrm{s}$

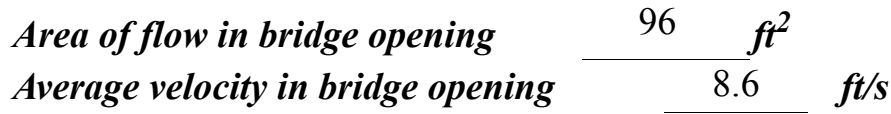

$\begin{array}{llll}\text { Maximum WSPRO tube velocity at bridge } & 11.1 \mathrm{ft} / \mathrm{s}\end{array}$

Water-surface elevation at Approach section with bridge $\quad 500.4$

Water-surface elevation at Approach section without bridge $\quad 497.5$

Amount of backwater caused by bridge $\quad 2.9$ it

500-year discharge $\quad 1,500 \quad \mathrm{ft}^{3} / \mathrm{s}$

Water-surface elevation in bridge opening $\quad 497.7$ ft

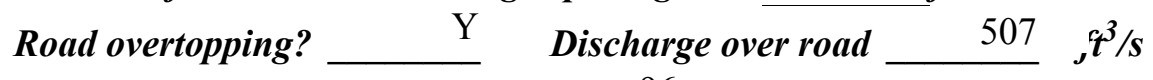

Area of flow in bridge opening $\quad 96 \quad \mathrm{ft}^{2}$

Average velocity in bridge opening $\quad 10.4 \mathrm{ft} / \mathrm{s}$

Maximum WSPRO tube velocity at bridge 13.3 , s

Water-surface elevation at Approach section with bridge 500.6

Water-surface elevation at Approach section without bridge $\quad 497.9$

Amount of backwater caused by bridge $\quad 2.7, t$

Incipient overtopping discharge $\quad \begin{array}{lll}750 & \mathrm{ft}^{3} / \mathrm{s}\end{array}$

Water-surface elevation in bridge opening $497.7 \quad t$

Area of flow in bridge opening $\quad 96 \quad \mathrm{ft}^{2}$

Average velocity in bridge opening $\quad 7.8 \quad \mathrm{ft} / \mathrm{s}$

Maximum WSPRO tube velocity at bridge $\quad 10.0 \mathrm{ft} / \mathrm{s}$

Water-surface elevation at Approach section with bridge

Water-surface elevation at Approach section without bridge

499.7

Amount of backwater caused by bridge $\quad 2.7$, t 


\section{Scour Analysis Summary}

\section{Special Conditions or Assumptions Made in Scour Analysis}

Scour depths were computed using the general guidelines described in Hydraulic Engineering Circular 18 (Richardson and Davis, 1995). Scour depths were calculated assuming an infinite depth of erosive material and a homogeneous particle-size distribution.

At this site, the modelled discharges resulted in orifice flow. Contraction scour at bridges with orifice flow is best estimated by use of the Chang pressure-flow scour equation (oral communication, J. Sterling Jones, October 4, 1996). Thus, contraction scour for these discharges was computed by use of the Chang equation (Richardson and Davis, 1995, p. 145-146). The results of the scour analysis are presented in tables 1 and 2 and the scour depths are presented graphically in figure 8.

For comparison, estimates of contraction scour were also computed for the discharges resulting in orifice flow by use of the Laursen clear-water contraction scour equation and the Umbrell pressure-flow equation (Richardson and Davis, 1995, p. 144). The results are presented in appendix F. For the 100-year and incipient roadway-overtopping discharges, which resulted in unsubmerged orifice flow, contraction scour was computed by substituting estimates for the depth of flow at the downstream bridge face in the contraction scour equations. Results with respect to these substitutions are also provided in appendix F.

Abutment scour for the right abutment was computed by use of the Froehlich equation (Richardson and Davis, 1995, p. 48, equation 28). Variables for the Froehlich equation include the Froude number of the flow approaching the embankments, the length of the embankment blocking flow, and the depth of flow approaching the embankment less any roadway overtopping.

Scour at the left abutment was computed by use of the HIRE equation (Richardson and Davis, 1995, p. 49, equation 29) because the HIRE equation is recommended when the length to depth ratio of the embankment blocking flow exceeds 25 . The variables used by the HIRE abutment-scour equation are defined the same as those defined for the Froehlich abutment-scour equation. 


\section{Scour Results}

100-yr discharge 500-yr discharge

Incipient

overtopping

Contraction scour:

(Scour depths in feet)

Main channel

Live-bed scour

Clear-water scour

Depth to armoring

Left overbank

Right overbank

Local scour:

Abutment scour

7.57 .9

6.9

11.1

Left abutment

11.8

10.5

Right abutment

Pier scour

Pier 1

Pier 2

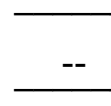

13.8

9.7

N/A N/

A $\mathrm{N} /$

$\mathrm{A}^{-}$

$--^{-}$

Pier 3

\section{Riprap Sizing}

Abutments:

Left abutment

Right abutment

Piers:

Pier 1

Pier 2

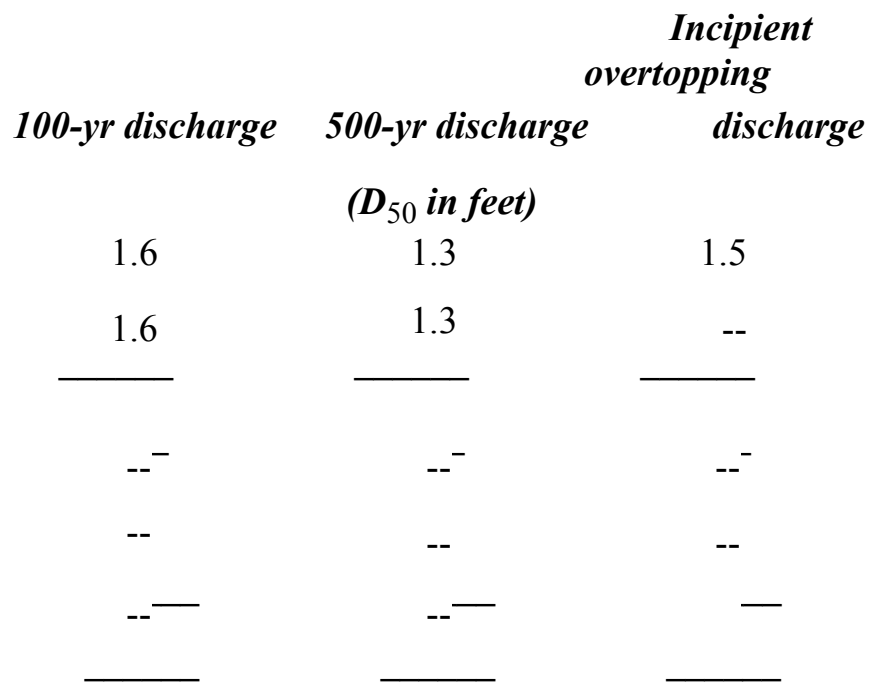




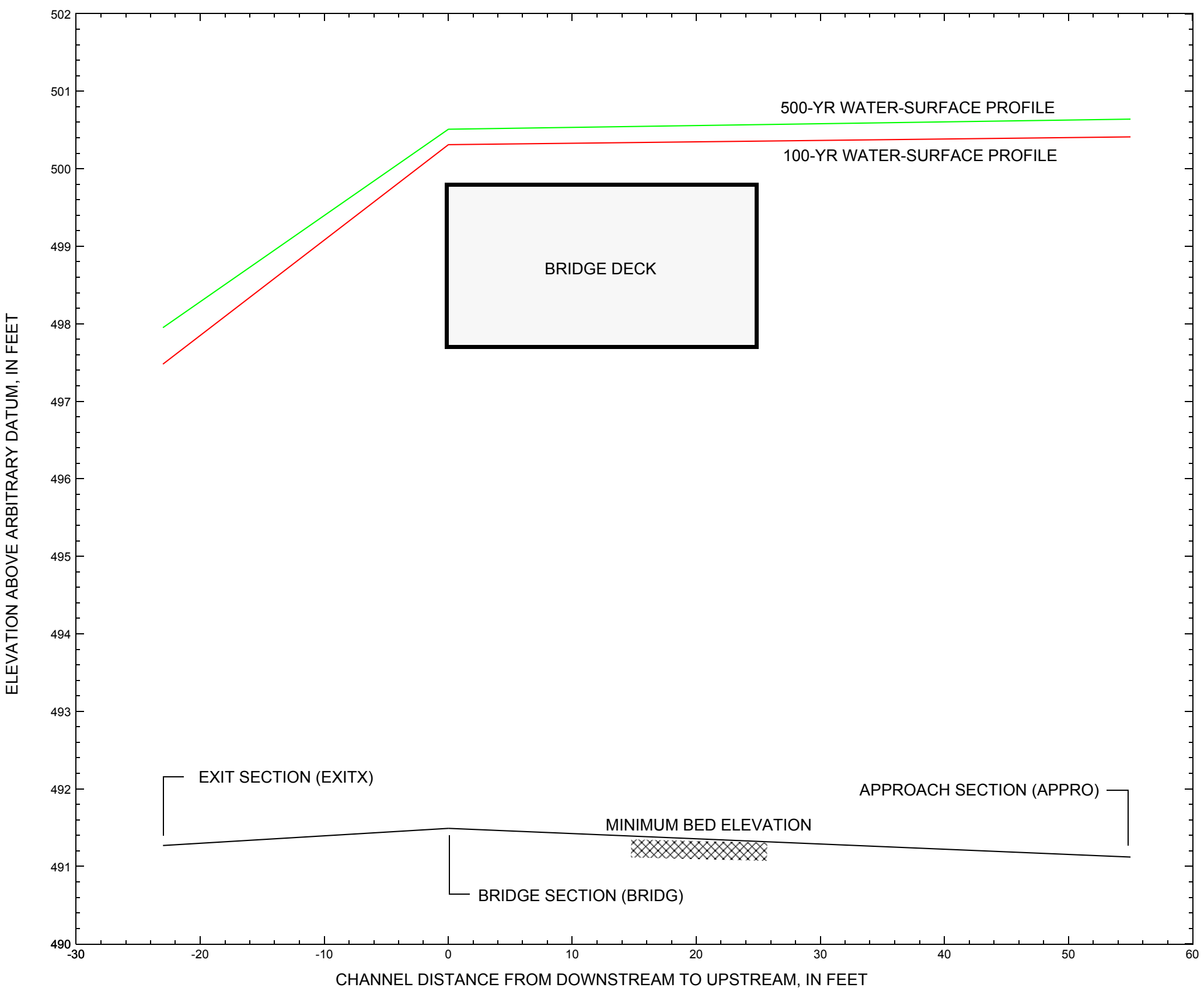

Figure 7. Water-surface profiles for the 100- and 500-yr discharges at structure NEWHTH00200017 on Town Highway 20, crossing Little Otter Creek, New Haven, Vermont. 


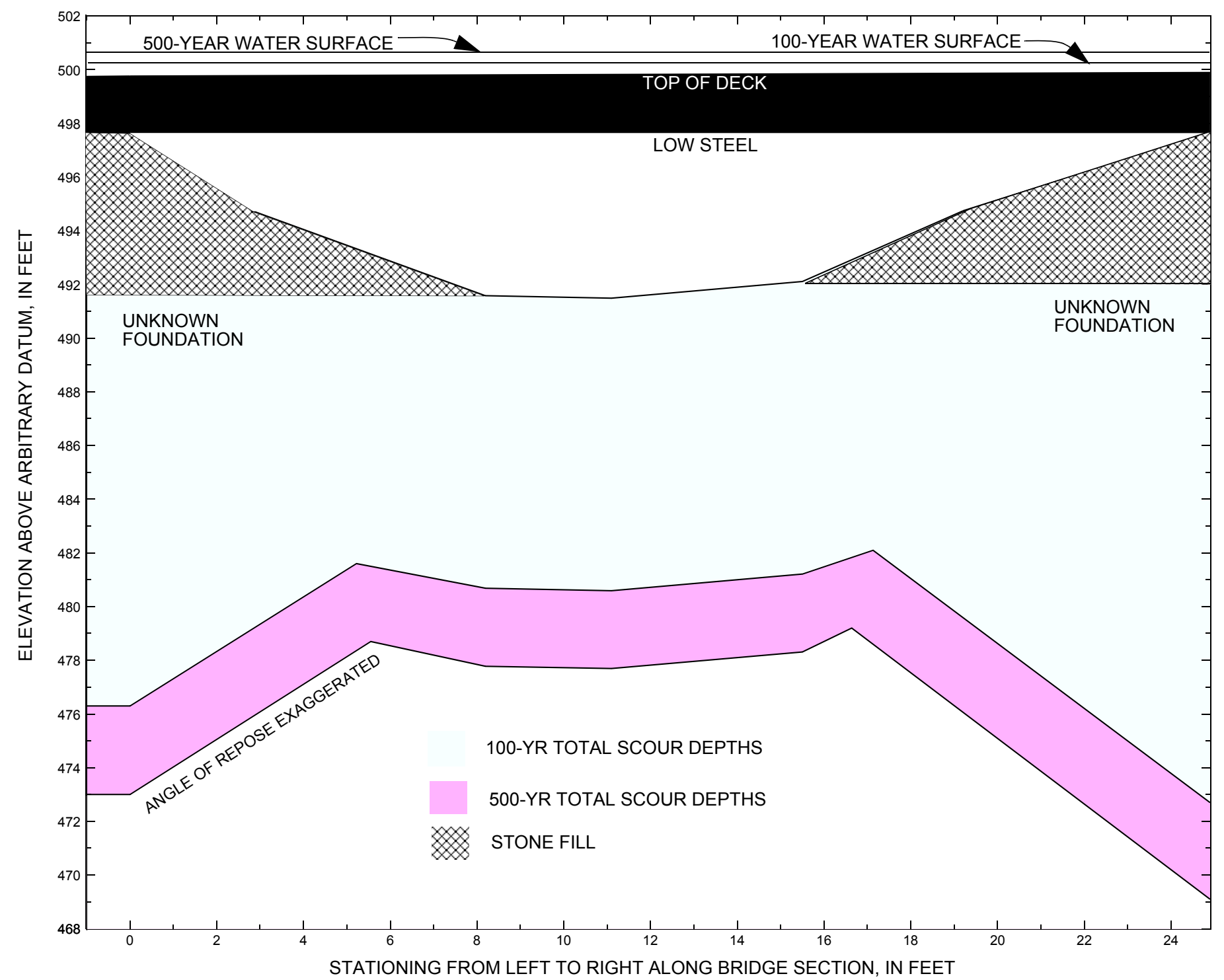

Figure 8. Scour elevations for the 100- and 500-yr discharges at structure NEWHTH00200017 on Town Highway 20, crossing Little Otter Creek, New Haven, Vermont. 
Table 1. Remaining footing/pile depth at abutments for the 100-yr discharge at structure NEWHTH00200017 on Town Highway 20, crossing Little Otter Creek, New Haven, Vermont.

[VTAOT, Vermont Agency of Transportation; --, no data]

\begin{tabular}{|c|c|c|c|c|c|c|c|c|c|c|c|}
\hline Description & Station $^{1}$ & $\begin{array}{l}\text { VTAOT } \\
\text { minimum } \\
\text { low-chord } \\
\text { elevation } \\
\text { (feet) }\end{array}$ & $\begin{array}{l}\text { Surveyed } \\
\text { minimum } \\
\text { low-chord } \\
\text { elevation } \\
\quad \text { (feet) }\end{array}$ & $\begin{array}{l}\text { Bottom of } \\
\text { footing } \\
\text { elevation } \\
\text { (feet) }\end{array}$ & $\begin{array}{c}\text { Channel } \\
\text { elevation at } \\
\text { abutment/ } \\
\text { pier }^{2} \\
\text { (feet) }\end{array}$ & $\begin{array}{l}\text { Contraction } \\
\text { scour depth } \\
\text { (feet) }\end{array}$ & $\begin{array}{l}\text { Abutment } \\
\text { scour } \\
\text { depth } \\
\text { (feet) }\end{array}$ & $\begin{array}{l}\text { Pier } \\
\text { scour } \\
\text { depth } \\
\text { (feet) }\end{array}$ & $\begin{array}{l}\text { Depth of } \\
\text { total scour } \\
\text { (feet) }\end{array}$ & $\begin{array}{c}\text { Elevation of } \\
\text { scour }^{2} \\
\text { (feet) }\end{array}$ & $\begin{array}{l}\text { Remaining } \\
\text { footing/pile } \\
\text { depth } \\
\text { (feet) }\end{array}$ \\
\hline \multicolumn{12}{|c|}{100 -yr. discharge is 1,120 cubic-feet per second } \\
\hline Left abutment & 0.0 & -- & 497.7 & -- & 494.7 & 10.9 & 7.5 & -- & 18.4 & 476.3 & -- \\
\hline Right abutment & 24.9 & -- & 497.7 & -- & 494.7 & 10.9 & 11.1 & -- & 22.0 & 472.7 & -- \\
\hline
\end{tabular}

1.Measured along the face of the most constricting side of the bridge.

2.Arbitrary datum for this study.

Table 2. Remaining footing/pile depth at abutments for the 500-yr discharge at structure NEWHTH00200017 on Town Highway 20, crossing Little Otter Creek, New Haven, Vermont.

[VTAOT, Vermont Agency of Transportation; --, no data]

\begin{tabular}{|c|c|c|c|c|c|c|c|c|c|c|c|}
\hline Description & Station $^{1}$ & $\begin{array}{l}\text { VTAOT } \\
\text { minimum } \\
\text { low-chord } \\
\text { elevation } \\
\text { (feet) }\end{array}$ & $\begin{array}{c}\text { Surveyed } \\
\text { minimum } \\
\text { low-chord } \\
\text { elevation } \\
\text { (feet) }\end{array}$ & $\begin{array}{c}\text { Bottom of } \\
\text { footing } \\
\text { elevation } \\
\text { (feet) }\end{array}$ & $\begin{array}{c}\text { Channel } \\
\text { elevation at } \\
\text { abutment/ } \\
\text { pier }^{2} \\
\text { (feet) }\end{array}$ & $\begin{array}{l}\text { Contraction } \\
\text { scour depth } \\
\text { (feet) }\end{array}$ & $\begin{array}{l}\text { Abutment } \\
\text { scour } \\
\text { depth } \\
\text { (feet) }\end{array}$ & $\begin{array}{l}\text { Pier } \\
\text { scour } \\
\text { depth } \\
\text { (feet) }\end{array}$ & $\begin{array}{l}\text { Depth of } \\
\text { total scour } \\
\text { (feet) }\end{array}$ & $\begin{array}{c}\text { Elevation of } \\
\text { scour }^{2} \\
\text { (feet) }\end{array}$ & $\begin{array}{c}\text { Remaining } \\
\text { footing/pile } \\
\text { depth } \\
\text { (feet) }\end{array}$ \\
\hline \multicolumn{12}{|c|}{500 -yr. discharge is 1,500 cubic-feet per second } \\
\hline Left abutment & 0.0 & -- & 497.7 & -- & 494.7 & 13.8 & 7.9 & -- & 21.7 & 473.0 & -- \\
\hline Right abutment & 24.9 & -- & 497.7 & -- & 494.7 & 13.8 & 11.8 & -- & 25.6 & 469.1 & -- \\
\hline
\end{tabular}

1.Measured along the face of the most constricting side of the bridge.

2.Arbitrary datum for this study. 


\section{SELECTED REFERENCES}

Arcement, G.J., Jr., and Schneider, V.R., 1989, Guide for selecting Manning's roughness coefficients for natural channels and flood plains: U.S. Geological Survey Water-Supply Paper 2339, 38 p.

Barnes, H.H., Jr., 1967, Roughness characteristics of natural channels: U.S. Geological Survey Water-Supply Paper 1849,213 p.

Benson, M. A., 1962, Factors Influencing the Occurrence of Floods in a Humid Region of Diverse Terrain: U.S. Geological Survey WaterSupply Paper 1580-B, 64 p.

Brown, S.A. and Clyde, E.S., 1989, Design of riprap revetment: Federal Highway Administration Hydraulic Engineering Circular No. 11, Publication FHWA-IP-89-016, 156 p.

Federal Highway Administration, 1983, Runoff estimates for small watersheds and development of sound design: Federal Highway Administration Report FHWA-RD-77-158.

Federal Highway Administration, 1993, Stream Stability and Scour at Highway Bridges: Participant Workbook: Federal Highway Administration Report FHWA-HI-91-011.

Froehlich, D.C., 1989, Local scour at bridge abutments in Ports, M.A., ed., Hydraulic Engineering--Proceedings of the 1989 National Conference on Hydraulic Engineering: New York, American Society of Civil Engineers, p. 13-18.

Hayes, D.C.,1993, Site selection and collection of bridge-scour data in Delaware, Maryland, and Virginia: U.S. Geological Survey WaterResources Investigation Report 93-4017, 23 p.

Interagency Advisory Committee on Water Data, 1982, Guidelines for determining flood flow frequency: U.S. Geological Survey, Bulletin 17B of the Hydrology Subcommittee, 190 p.

Johnson, C.G. and Tasker, G.D.,1974, Progress report on flood magnitude and frequency of Vermont streams: U.S. Geological Survey OpenFile Report 74-130, 37 p.

Lagasse, P.F., Schall, J.D., Johnson, F., Richardson, E.V., Chang, F., 1995, Stream Stability at Highway Structures: Federal Highway Administration Hydraulic Engineering Circular No. 20, Publication FHWA-IP-90-014, 144 p.

Laursen, E.M., 1960, Scour at bridge crossings: Journal of the Hydraulics Division, American Society of Civil Engineers, v. 86, no. HY2, p. 39-53.

Potter, W. D., 1957a, Peak rates of runoff in the Adirondack, White Mountains, and Maine woods area, Bureau of Public Roads

Potter, W. D., 1957b, Peak rates of runoff in the New England Hill and Lowland area, Bureau of Public Roads

Richardson, E.V. and Davis, S.R., 1995, Evaluating scour at bridges: Federal Highway Administration Hydraulic Engineering Circular No. 18, Publication FHWA-IP-90-017, 204 p.

Richardson, E.V., Simons, D.B., and Julien, P.Y., 1990, Highways in the river environment: Federal Highway Administration Publication FHWA-HI-90-016.

Ritter, D.F., 1984, Process Geomorphology: W.C. Brown Co., Debuque, Iowa, 603 p.

Shearman, J.O., 1990, User's manual for WSPRO--a computer model for water surface profile computations: Federal Highway Administration Publication FHWA-IP-89-027, 187 p.

Shearman, J.O., Kirby, W.H., Schneider, V.R., and Flippo, H.N., 1986, Bridge waterways analysis model; research report: Federal Highway Administration Publication FHWA-RD-86-108, 112 p.

Talbot, A.N., 1887, The determination of water-way for bridges and culverts.

U.S. Geological Survey, 1963, Monkton Boro, Vermont 7.5 Minute Series quadrangle map: U.S. Geological Survey Topographic Maps, Photoinspected 1983, Photorevised 1972, Scale 1:24,000. 


\section{APPENDIX A:}

WSPRO INPUT FILE 


\section{WSPRO INPUT FILE}

GR

GR

GR

GR

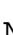

SA

*

X

*

BR

GR

GR

*

CD

$\mathrm{N}$

*

*

XR

GR

GR

GR

*

AS

GR

GR

GR

GR

*

$\mathrm{N}$

SA

U.S. Geological Survey WSPRO Input File newh017.wsp Hydraulic analysis for structure NEWHTH00200017 Date: 18-JUN-97 Town Highway 20, Little Otter Creek, Bridge 17, New Haven, VT

ECW

* *0.005

$\begin{array}{lllllllllllllllllllll}6 & 29 & 30 & 552 & 553 & 551 & 5 & 16 & 17 & 13 & 3 & * & 15 & 14 & 23 & 21 & 11 & 12 & 4 & 7 & 3\end{array}$

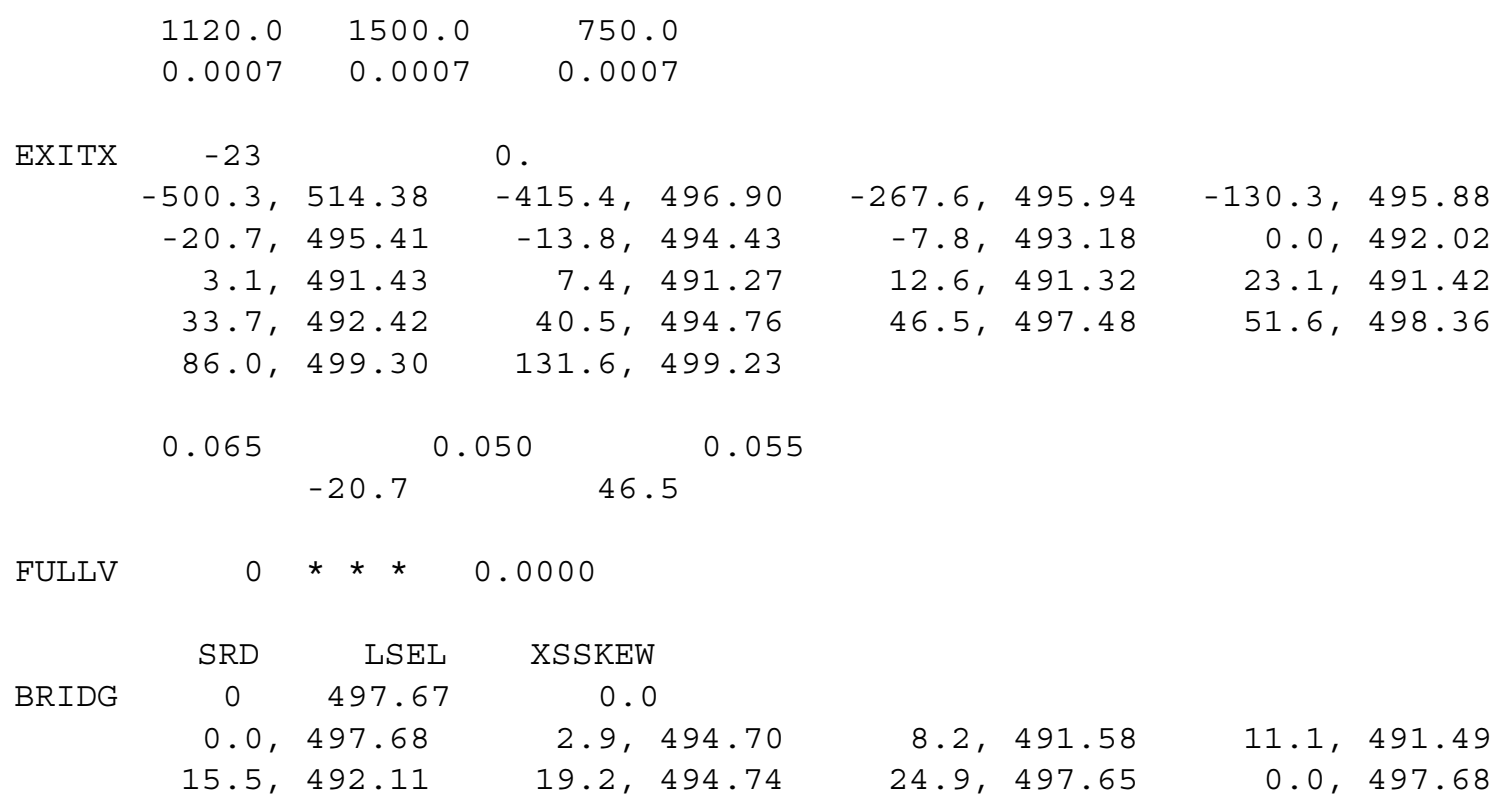




\section{APPENDIX B: \\ WSPRO OUTPUT FILE}




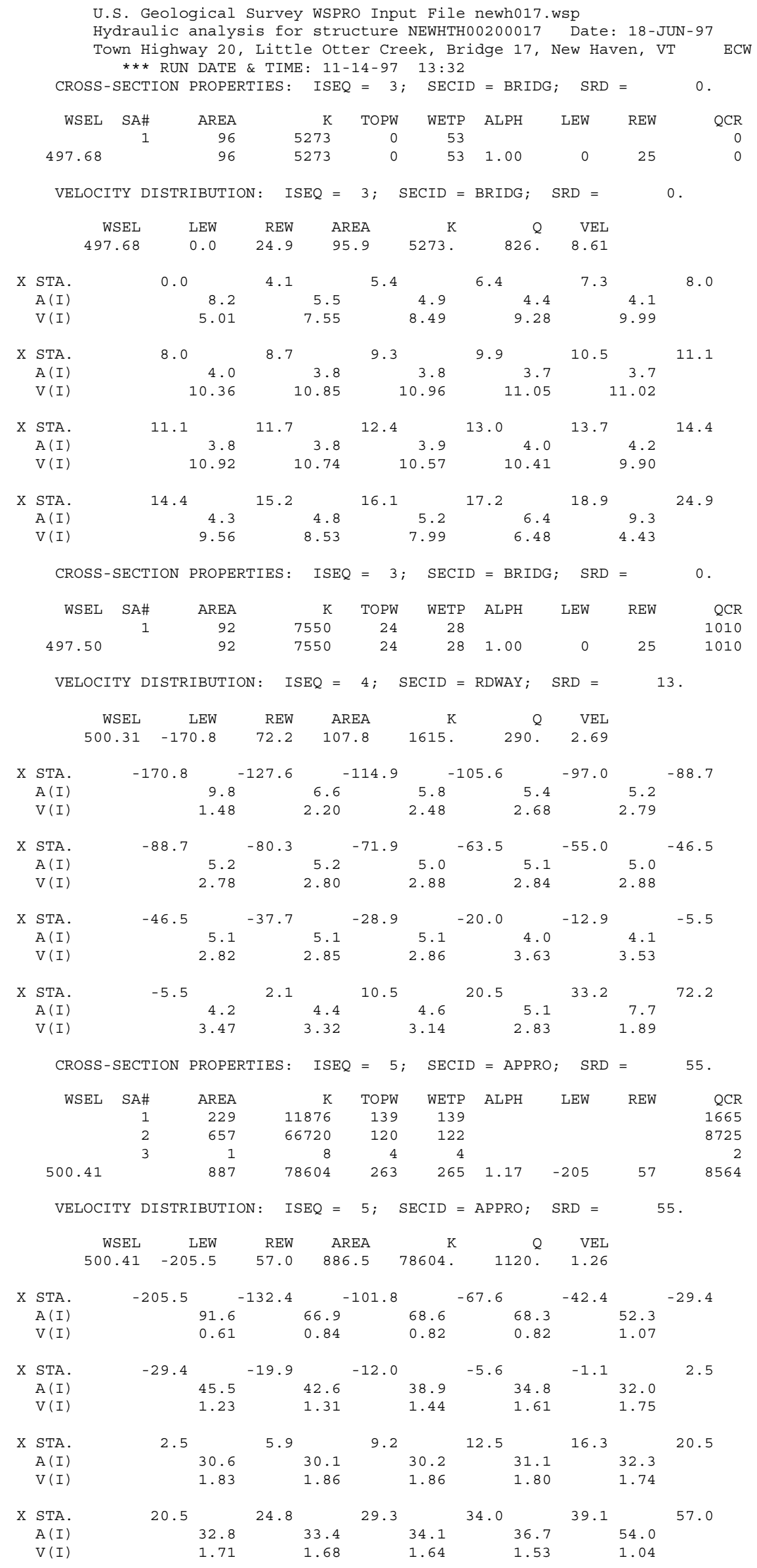


WSPRO OUTPUT FILE (continued)

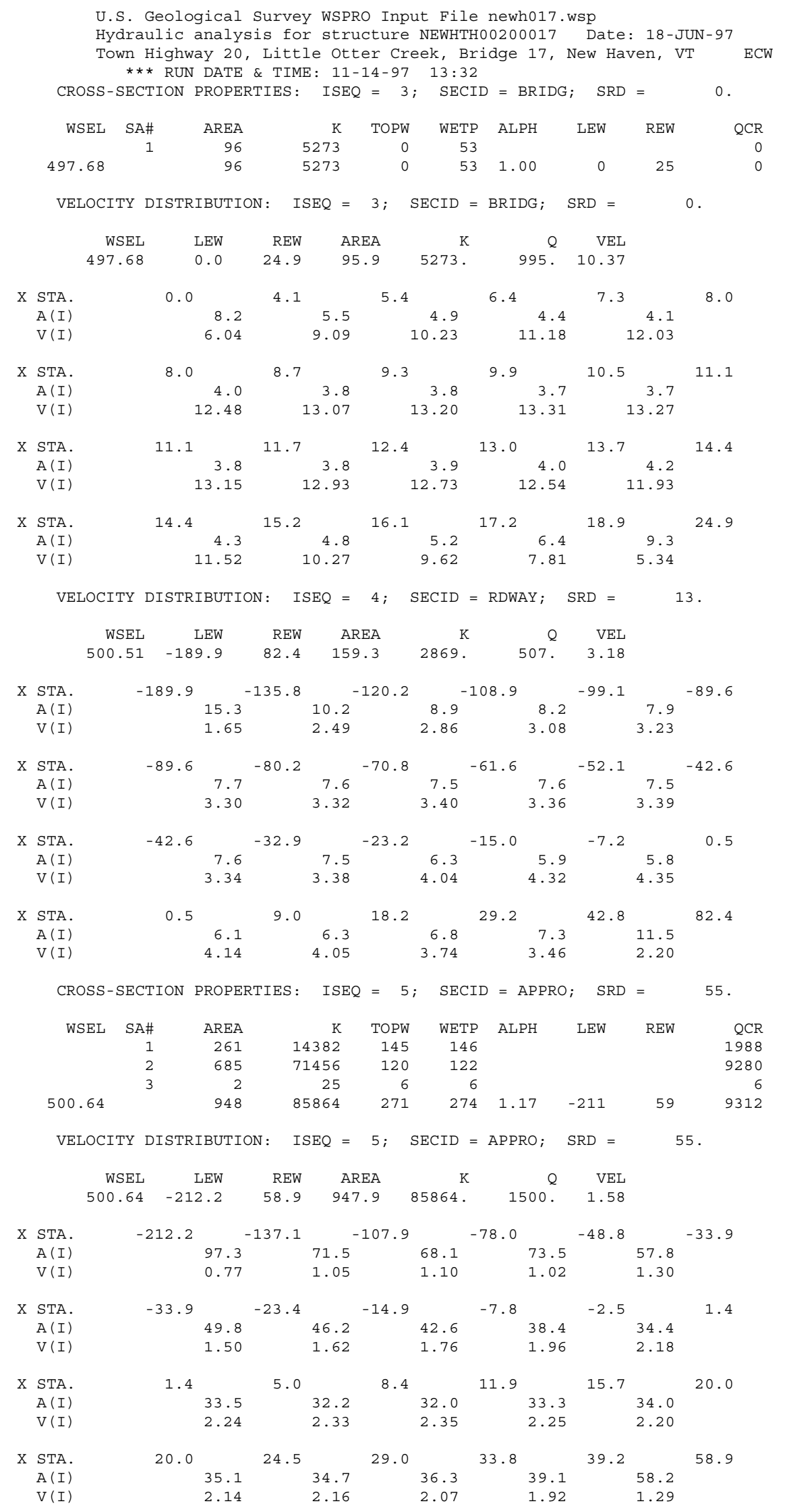


WSPRO OUTPUT FILE (continued)

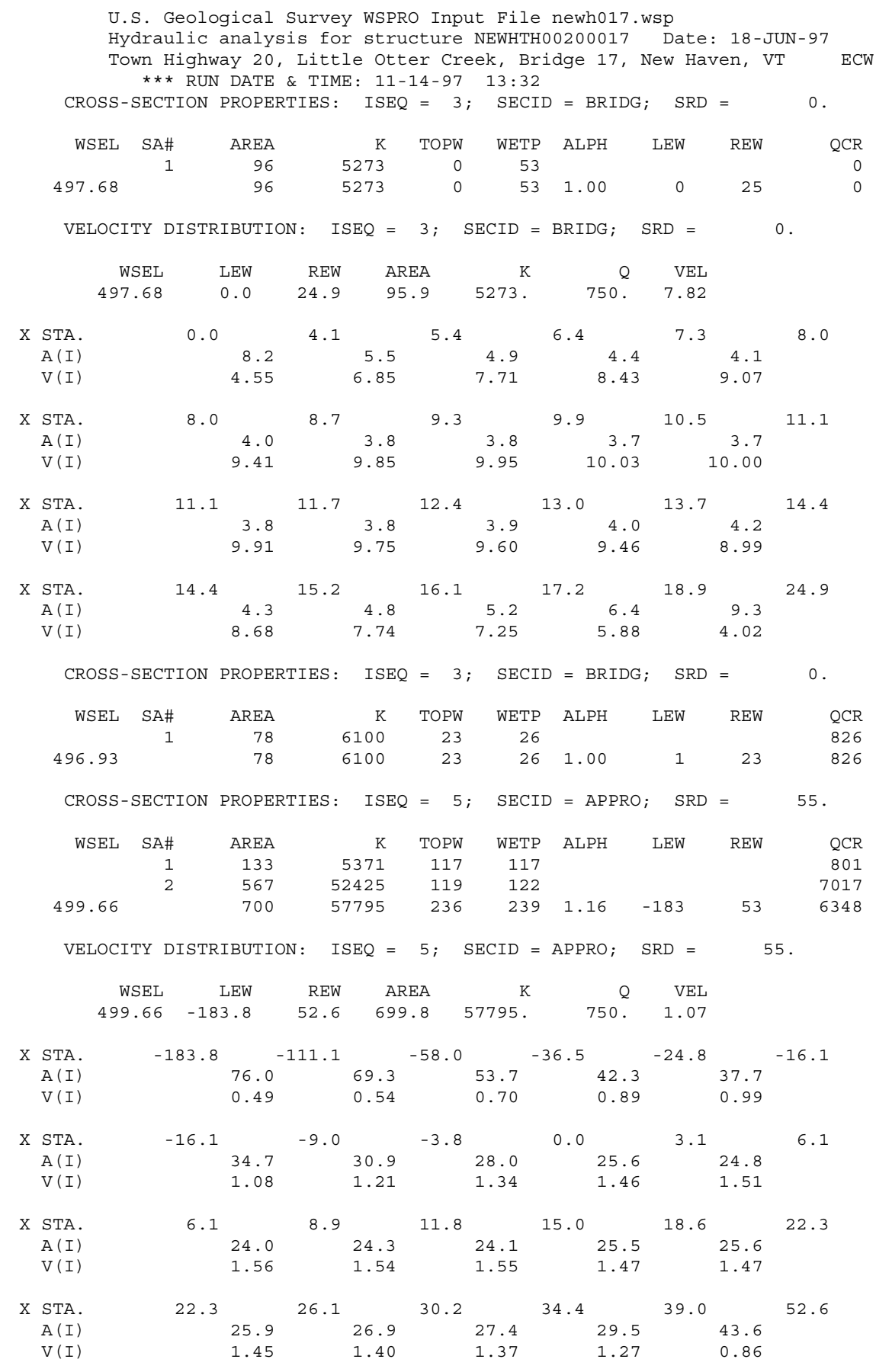


WSPRO OUTPUT FILE (continued)

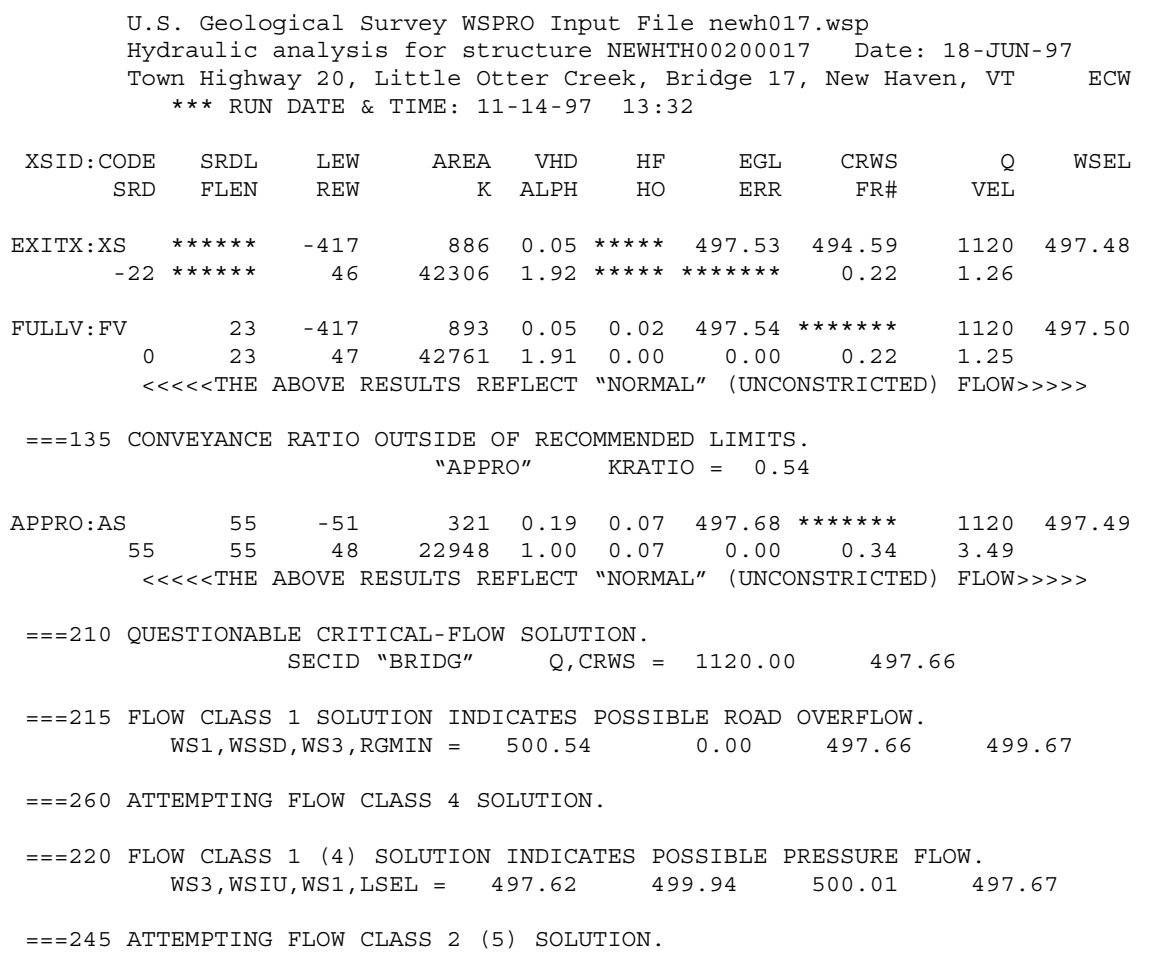


WSPRO OUTPUT FILE (continued)

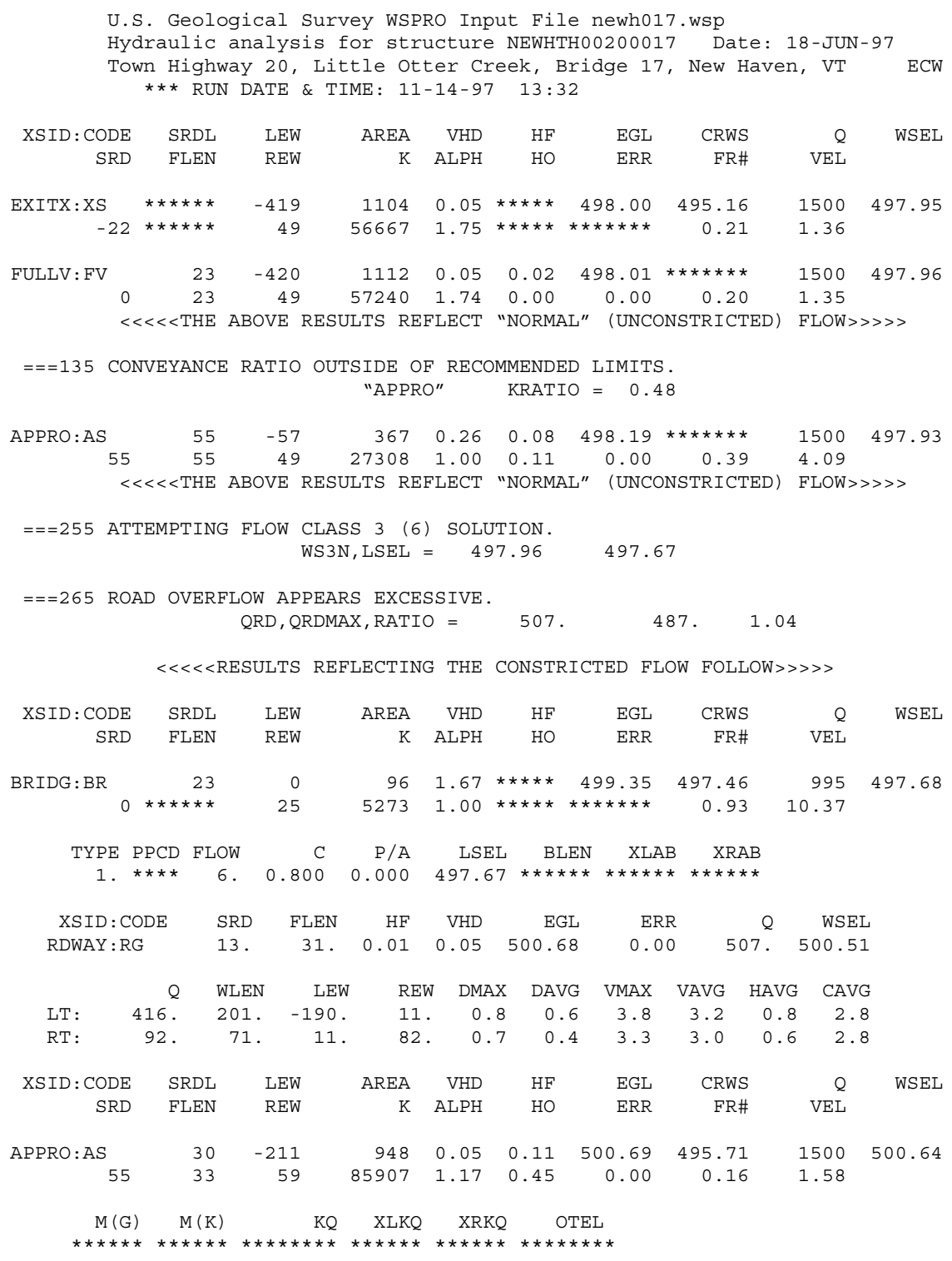

$<<<<$ END OF BRIDGE COMPUTATIONS $>>>>>$

FIRST USER DEFINED TABLE.

\begin{tabular}{|c|c|c|c|c|c|c|c|c|}
\hline XSID : CODE & SRD & LEW & REW & $\mathrm{Q}$ & K & AREA & VEL & WSEI \\
\hline EXITX:XS & -23 & -420 & 49. & 1500. & 56667. & 1104. & 1.36 & 497.95 \\
\hline FULLV : FV & 0 . & -421 & 49. & 1500 . & 57240 . & 1112. & 1.35 & 497.96 \\
\hline BRIDG : BR & 0 . & 0 . & 25. & 995. & 5273. & 96. & 10.37 & 497.68 \\
\hline RDWAY : RG & 13. * & $\star \star \star \star \star \star \star ~$ & 416. & 507. & 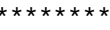 & $\star \star \star * * * *$ & 2.00 & 500.51 \\
\hline APPRO : AS & 55. & -212 & 59. & 1500. & 85907 . & 948. & 1.58 & 500.64 \\
\hline XSID : CODE & XLKQ & XRKQ & $\mathrm{K}$ & & & & & \\
\hline
\end{tabular}

SECOND USER DEFINED TABLE.

$\begin{array}{lcrrrrrrrr}\text { XSID : CODE } & \text { CRWS } & \text { FR\# } & \text { YMIN } & \text { YMAX } & \text { HF } & \text { HO } & \text { VHD } & \text { EGL } & \text { WSEL } \\ \text { EXITX:XS } & 495.16 & 0.21 & 491.27 & 514.38 * * * * * * * * * * * & 0.05 & 498.00 & 497.95 \\ \text { FULLV : FV } & * * * * * * * * & 0.20 & 491.27 & 514.38 & 0.02 & 0.00 & 0.05 & 498.01 & 497.96 \\ \text { BRIDG : BR } & 497.46 & 0.93 & 491.49 & 497.68 * * * * * * * * * * * & 1.67 & 499.35 & 497.68 \\ \text { RDWAY: RG } & * * * * * * * * * * * * * * * * & 499.67 & 519.41 & 0.01 * * * * * * & 0.05 & 500.68 & 500.51 \\ \text { APPRO:AS } & 495.71 & 0.16 & 491.12 & 506.78 & 0.11 & 0.45 & 0.05 & 500.69 & 500.64\end{array}$


WSPRO OUTPUT FILE (continued)

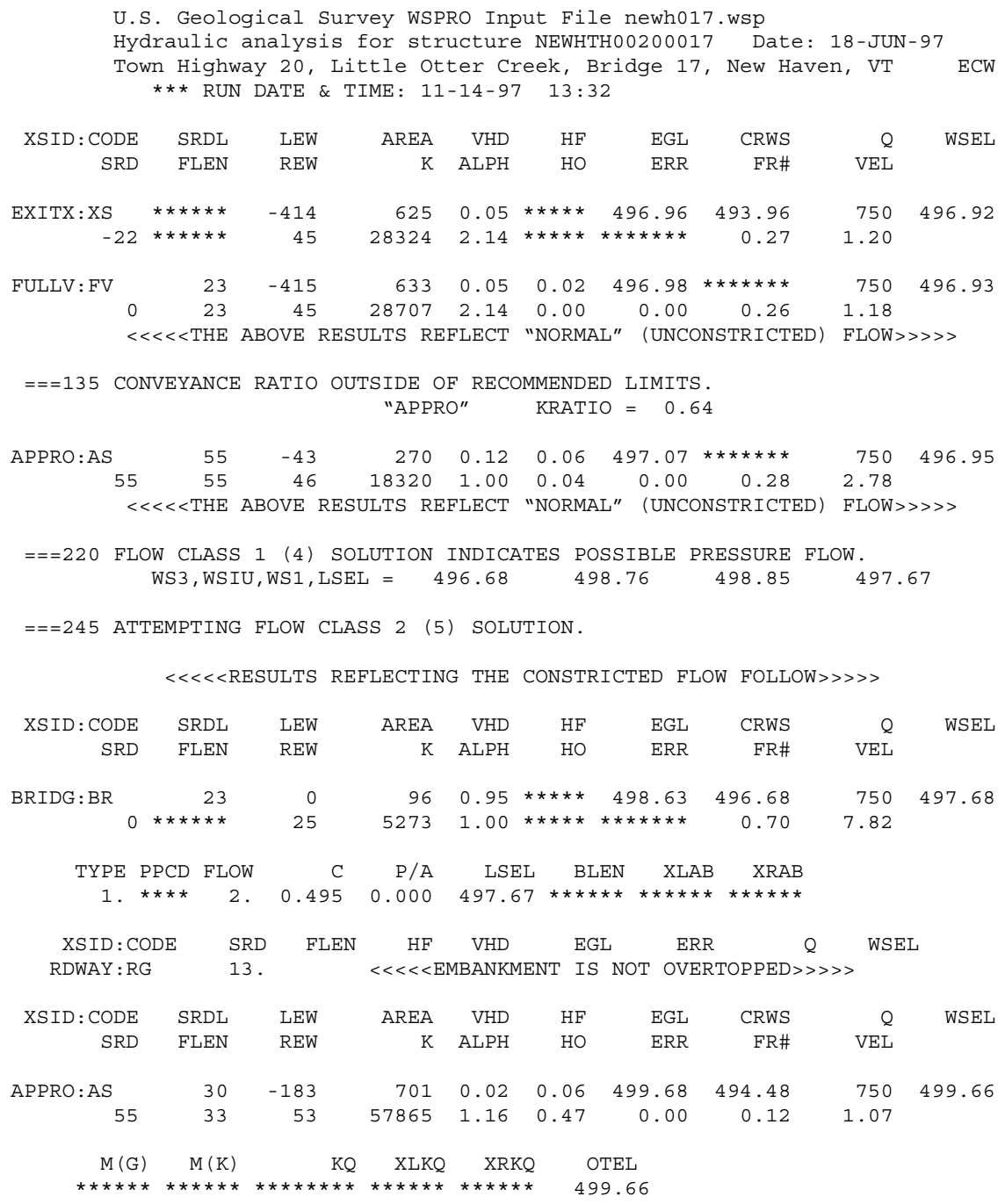

FIRST USER DEFINED TABLE.

\begin{tabular}{|c|c|c|c|c|c|c|c|c|}
\hline XSID : CODE & SRD & LEW & REW & Q & $\mathrm{K}$ & AREA & VEL & WSEL \\
\hline EXITX:XS & -23. & -415 . & 45. & 750. & 28324 . & 625. & 1.20 & 496.92 \\
\hline FULLV: FV & 0 . & -416 & 45. & 750. & 28707 . & 633. & 1.18 & 496.93 \\
\hline BRIDG : BR & 0 . & 0 . & 25 . & 750 & 5273. & 96. & 7.82 & 497.6 \\
\hline RDWAY : RG & $13 . *$ & $* \star * \star * * *$ & $* * *$ & $0 . *$ & $\star \star \star \star \star \star * \star *$ & $\star \star \star \star \star *$ & $2.00 *$ & $\star * * * * *$ \\
\hline APPRO: AS & 55. & -184 & 53. & 750. & 57865. & 701. & 1.07 & 499.66 \\
\hline XSID : CODE & XLKQ & XRKQ & $\mathrm{K}$ & & & & & \\
\hline
\end{tabular}

SECOND USER DEFINED TABLE.

\begin{tabular}{|c|c|c|c|c|c|c|c|c|c|}
\hline XSID: CODE & CRWS & FR\# & YMIN & YMAX & $\mathrm{HF}$ & HO & VHD & EGL & WSEL \\
\hline EXITX:XS & 493.96 & 0.27 & 491.27 & $514.38 *$ & 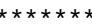 & 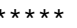 & 0.05 & 496.96 & 496 \\
\hline FULLV: FV & 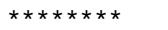 & 0.26 & 491.27 & 514.38 & 0.02 & 0.00 & 0.05 & 496.98 & 4 \\
\hline BRIDG : BR & 496.68 & 0.70 & 491.49 & $497.68 *$ & $\star \star \star \star \star * \star * *$ & $\star \star \star * \star *$ & 0.95 & 498.63 & 497. \\
\hline RDWAY : RG & 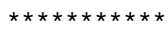 & $\star \star \star \star \star *$ & 499.67 & $519.41 *$ & 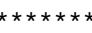 & 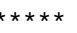 & 0.02 & $499.96 *$ & 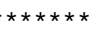 \\
\hline APPRO:AS & 494.48 & 0.12 & 491.12 & 506.78 & 0.06 & 0.47 & 0.02 & 499.68 & 499. \\
\hline
\end{tabular}

NORMAL END OF WSPRO EXECUTION 


\section{APPENDIX C: \\ STONE FILL MATERIAL \\ PARTICLE-SIZE DISTRIBUTION}




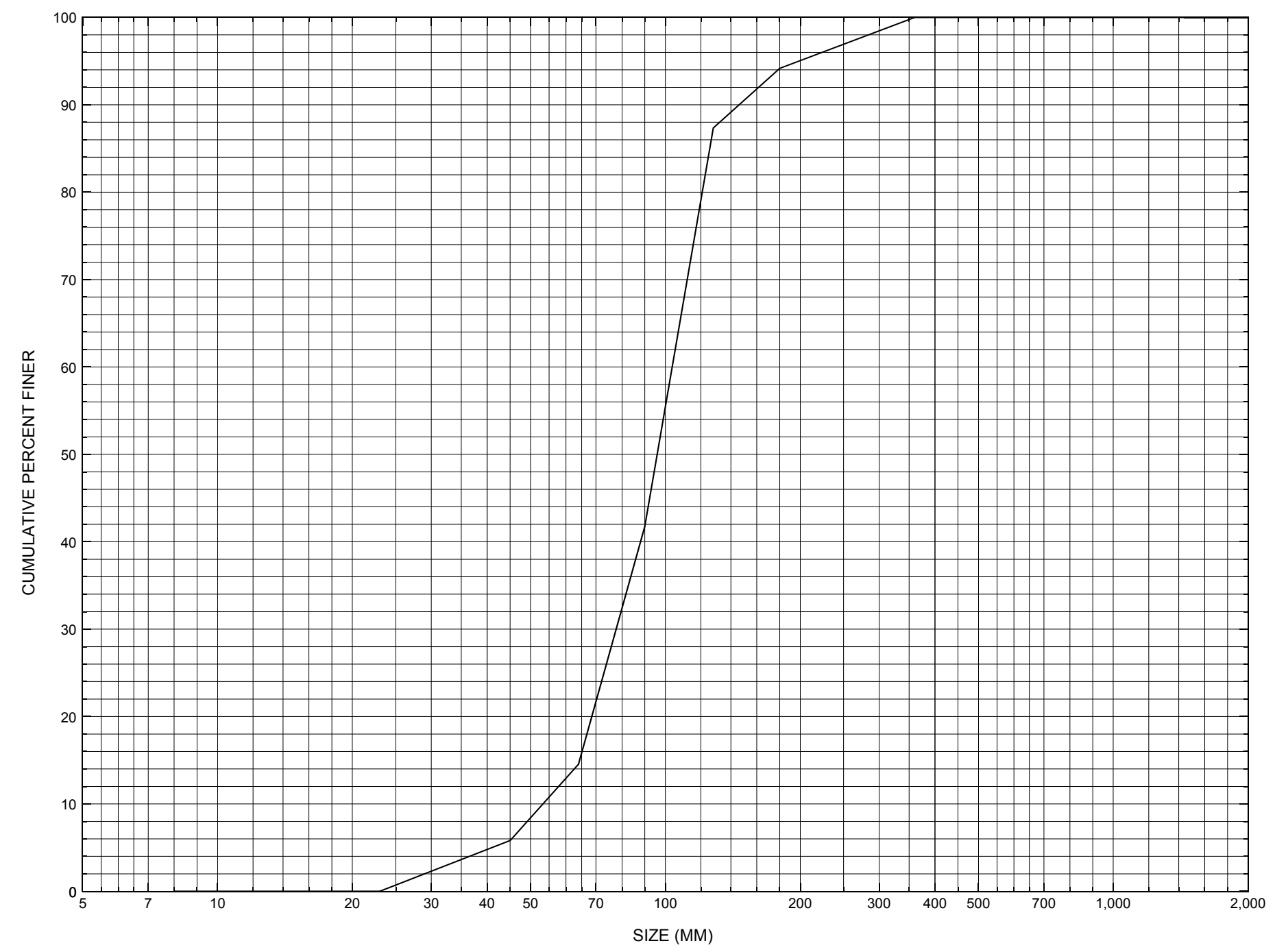

Appendix C. Stone fill material particle-size distribution for a pebble count at the downstream bridge face of structure NEWHTH00200017, in New Haven, Vermont. 


\section{APPENDIX D: \\ HISTORICAL DATA FORM}




\section{Structure Number NEWHTH00200017}

\section{General Location Descriptive}

Data collected by (First Initial, Full last name) $\underline{\mathbf{L}}$. Medalie

Date $(M M / D D / Y Y)+12 / \underline{15} / \underline{95}$

Highway District Number (I - 2; nn) $\mathbf{0 5}$

Town (FIPS place code; I - 4; nnnnn) $\mathbf{4 8 7 0 0}$

Waterway (I - 6) BR LITTLE OTTER CREEK

Route Number $\mathbf{C 3 0 2 0}$

Topographic Map Monkton Boro

Latitude (I - 16; nnnn.n) $\mathbf{4 4 0 8 8}$
County (FIPS county code; I - 3; nnn)

Mile marker (I - 11; nnn.nnn) $\underline{\mathbf{0 0 0 0 0 0}}$

Road Name (I - 7): -

Vicinity (I - 9) 0.2 MI TO JCT C3 TH 8

Hydrologic Unit Code: 2010002

Longitude (i - 17; nnnnn.n) $\mathbf{7 3 1 0 8}$

\section{Select Federal Inventory Codes}

FHWA Structure Number $(I-8) \underline{10011300170113}$

Maintenance responsibility $(I-21 ; n n) \quad \mathbf{0 3} \quad$ Maximum span length $(I-48$; $n n n n) \underline{\mathbf{0 0 2 8}}$

Year built (I - 27; YYYY) 1919

Structure length (I - 49; nnnnnn) $\underline{\mathbf{0 0 0 0 3 2}}$

Average daily traffic, ADT (I - 29; nnnnnn) $\mathbf{0 0 0 0 7 0}$ Deck Width (I- 52; nn.n) 245

Year of ADT (I-30; YY) $\mathbf{9 2}$

Channel \& Protection $(I-61 ; n) \underline{\mathbf{5}}$

Opening skew to Roadway $(I-34 ; n n) \quad \mathbf{0 0}$

Waterway adequacy $(I-71 ; n)$

Operational status $(I-41 ; X)$ A

Underwater Inspection Frequency $(I-92 B ; X Y Y) \_\mathbf{N}$

Structure type (I - 43; nnn) $\mathbf{3 0 2}$

Year Reconstructed (I - 106) 1988

Approach span structure type $(I-44 ; n n n) \quad \mathbf{0 0 0}$

Clear span (nnn.n ft) $\mathbf{2 5}$

Number of spans (I - 45; nnn) $\mathbf{0 0 1}$

Vertical clearance from streambed (nnn.n ft) $\underline{\mathbf{4 . 4}}$

Number of approach spans (I-46; nnnn) $\underline{\mathbf{0 0 0 0}}$ Waterway of full opening $\left(n n n . n \mathrm{ft}^{2}\right) \underline{\mathbf{1 1 0 . 4}}$

Comments:

According to the structural inspection report dated $12 / 8 / 94$, the bridge deck is concrete with a gravel wearing surface. The abutments and backwalls are concrete. Voided sections are present along the entire bottom of the RABUT and along the bottom right half of the LABUT. The left half of each abutment appears to have been poured on a uniform layer of stones and boulders, some of which are starting to wash away at the RABUT side. The upstream half of the RABUT may be partially resting on ledge. There is spalling along the bottoms of both abutments and the right half of the faces. Some stone and boulder stone fill has been placed on the embankments at the ends of each abutment. 


\section{Bridge Hydrologic Data}

Is there hydrologic data available? $\underline{\mathbf{N}}$ if No, type ctrl-n $h \quad$ VTAOT Drainage area $\left(m i^{2}\right)$ : -

Terrain character:

Stream character \& type: -

Streambed material:

Discharge Data (cfs):

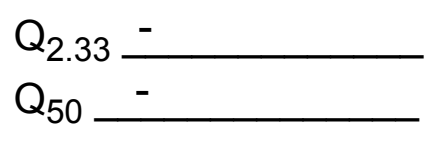

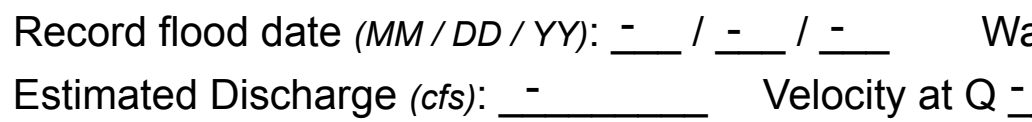

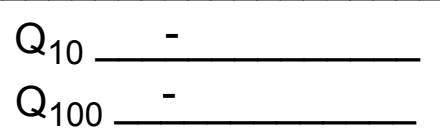

$\mathrm{Q}_{25}$

Water surface elevation $(f t):-$ $(\mathrm{ft} / \mathrm{s}):$

Ice conditions (Heavy, Moderate, Light) : -

Debris (Heavy, Moderate, Light):

The stage increases to maximum highwater elevation (Rapidly, Not rapidly):

The stream response is (Flashy, Not flashy):

Describe any significant site conditions upstream or downstream that may influence the stream's stage: -

Watershed storage area (in percent):

The watershed storage area is: - (1-mainly at the headwaters; 2- uniformly distributed; 3-immediatly upstream oi the site)

Water Surface Elevation Estimates for Existing Structure:

\begin{tabular}{|l|l|l|l|l|l|}
\hline Peak discharge frequency & $Q_{2.33}$ & $Q_{10}$ & $Q_{25}$ & $Q_{50}$ & $Q_{100}$ \\
Water surface elevation (ft)) & - & - & - & - & - \\
Velocity (ft/sec) & - & - & - & - & - \\
\hline
\end{tabular}

Long term stream bed changes: -

Is the roadway overtopped below the $Q_{100}$ ? (Yes, No, Unknown):

Frequency: -

Relief Elevation (ft):

Discharge over roadway at $Q_{100}\left(f^{3} / \mathrm{sec}\right)$ :

Are there other structures nearby? (Yes, No, Unknown): -

Upstream distance (miles):

Town: If No or Unknown, type ctrl-n os

Highway No. : Structure No. : Year Built:

Clear span (ft): Clear Height $(f t)$ : Full Waterway $\left(f^{2}\right)$ : 
Downstream distance (miles): Town: Year Built:

Highway No. : Structure No. : Structure Type:

Clear span (ft): Clear Height $(f t)$ : Full Waterway $\left(f^{2}\right)$ : -

Comments:

\section{USGS Watershed Data}

Watershed Hydrographic Data

Drainage area $(D A) \underline{\mathbf{1 0 . 8 1}} \mathrm{mi}^{2}$

Watershed storage (ST)

Bridge site elevation $\mathbf{2 7 0} \mathrm{ft}$ $\%$

Main channel length $\mathbf{7 . 0 7}$ mi

$10 \%$ channel length elevation $\mathbf{2 7 0}$

Lake/pond/swamp area

0.378 $\mathrm{mi}^{2}$

Main channel slope

(S) 11.32 $\mathrm{ft} / \mathrm{mi}$

Headwater elevation 470 $\mathrm{ft}$

Watershed Precipitation Data

Average site precipitation in Average headwater precipitation in

Maximum 2yr-24hr precipitation event $(124,2)$ in

Average seasonal snowfall (Sn) $\mathrm{ft}$ 


\section{Bridge Plan Data}

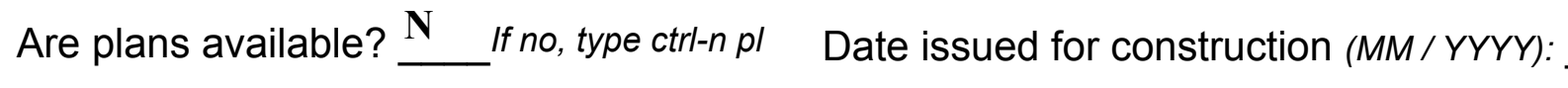

Project Number

Minimum channel bed elevation:

Low superstructure elevation: USLAB DSLAB USRAB DSRAB Benchmark location description:

NO BENCHMARK INFORMATION AVAILABLE

Reference Point (MSL, Arbitrary, Other): Datum (NAD27, NAD83, Other):

Foundation Type: 4

If 1 : Footing Thickness

If 2: Pile Type:

If 3: Footing bottom elevation:

Is boring information available? $\mathbf{N}$ Foundation Material Type: $\mathbf{3}$ (1-Spreadfooting; 2-Pile; 3- Gravity; 4-Unknown) Footing bottom elevation: -

Briefly describe material at foundation bottom elevation or around piles:

NO FOUNDATION INFORMATION AVAILABLE

Comments:

NO PLANS AVAILABLE 


\section{Cross-sectional Data}

Is cross-sectional data available? $\underline{\mathbf{Y}}$

If no, type ctrl-n xs

Source (FEMA, VTAOT, Other)? VTAOT

This is a cross-section of the upstream face. The low chord elevation is from the survey log

Comments: done for this report on $06 / 11 / 96$. The low cord to bed length data is from the sketch

attached to a bridge inspection report dated 12/08/92. The sketch was done on 11/24/92.

\begin{tabular}{|c|c|c|c|c|c|c|c|c|c|c|c|}
\hline Station & 0 & 6.3 & 12.6 & 18.7 & 25 & - & - & - & - & - & - \\
\hline Feature & LAB & - & - & - & RAB & - & - & - & - & - & - \\
\hline $\begin{array}{l}\text { Low chord } \\
\text { elevation }\end{array}$ & 497.7 & 497.7 & 497.7 & 497.7 & 497.7 & - & - & - & - & - & - \\
\hline $\begin{array}{l}\text { Bed } \\
\text { elevation }\end{array}$ & 496.1 & 492.7 & 491.9 & 493.1 & 497.2 & - & - & - & - & - & - \\
\hline $\begin{array}{l}\text { Low chord } \\
\text { to bed }\end{array}$ & 1.6 & 5 & 5.8 & 4.6 & 0.5 & - & - & - & - & - & - \\
\hline Station & - & - & - & - & - & - & - & - & - & - & - \\
\hline Feature & - & - & - & - & - & - & - & - & - & - & - \\
\hline $\begin{array}{l}\text { Low chord } \\
\text { elevation }\end{array}$ & - & - & - & - & - & - & - & - & - & - & - \\
\hline $\begin{array}{l}\text { Bed } \\
\text { elevation }\end{array}$ & - & - & - & - & - & - & - & - & - & - & - \\
\hline $\begin{array}{l}\text { Low chord } \\
\text { to bed }\end{array}$ & - & - & - & - & - & - & - & - & - & - & - \\
\hline
\end{tabular}

Source (FEMA, VTAOT, Other)?

Comments:

\begin{tabular}{|c|c|c|c|c|c|c|c|c|c|c|c|}
\hline Station & - & - & - & - & - & - & - & - & - & - & - \\
\hline Feature & - & - & - & - & - & - & - & - & - & - & - \\
\hline $\begin{array}{l}\text { Low chord } \\
\text { elevation }\end{array}$ & - & - & - & - & - & - & - & - & - & - & - \\
\hline $\begin{array}{l}\text { Bed } \\
\text { elevation }\end{array}$ & - & - & - & - & - & - & - & - & - & - & - \\
\hline $\begin{array}{l}\text { Low chord } \\
\text { to bed }\end{array}$ & - & - & - & - & - & - & - & - & - & - & - \\
\hline Station & - & - & - & - & - & - & - & - & - & - & - \\
\hline Feature & - & - & - & - & - & - & - & - & - & - & - \\
\hline $\begin{array}{l}\text { Low chord } \\
\text { elevation }\end{array}$ & - & - & - & - & - & - & - & - & - & - & - \\
\hline $\begin{array}{l}\text { Bed } \\
\text { elevation }\end{array}$ & - & - & - & - & - & - & - & - & - & - & - \\
\hline $\begin{array}{l}\text { Low chord } \\
\text { to bed }\end{array}$ & - & - & - & - & - & - & - & - & - & - & - \\
\hline
\end{tabular}


APPENDIX E:

LEVEL I DATA FORM 
U. S. Geological Survey

Bridge Field Data Collection and Processing Form

Qa/Qc Check by: EW

Date: $7 / 11 / 96$

\section{Structure Number}

NEWHTH00200017

\section{A. General Location Descriptive}

1. Data collected by (First Initial, Full last name) $\underline{\mathbf{R}}$. BURNS

2. Highway District Number $\mathbf{0 5}$

Date $(M M / D D / Y Y) \underline{06} / \underline{11} / \underline{1996}$

County Addison (001)

Waterway (I - 6) Little Otter Creek

Town New Haven (48700)

Route Number TH020

Road Name Quarry Road

3. Descriptive comments:

Hydrologic Unit Code: 02010002

Located 0.2 miles from junction between TH20 and TH8. The bridge has a concrete deck and concrete abutments, with stone fill along the roadway embankments.

\section{B. Bridge Deck Observations}
4. Surface cover.
RBUS 7
LBDS 7
RBDS 5
Overall 7

(2b us,ds,lb,rb: 1- Urban; 2- Suburban; 3- Row crops; 4- Pasture; 5- Shrub- and brushland; 6- Forest; 7- Wetland)
5. Ambient water surface... US 1
UB 1
DS 1
(1- pool; 2- riffle)

6. Bridge structure type 1 (1- single span; 2- multiple span; 3- single arch; 4- multiple arch; 5-cylindrical culvert; 6- box culvert; or 7- other)
7. Bridge length $\mathbf{3 2}$
(feet)
Span length $\underline{\mathbf{2 8}}$
(feet)
Bridge width 24.5 (feet)

\section{Road approach to bridge:}
8. LB 0
RB 2
( 0 even, 1- lower, 2- higher)
9. LB_2
RB $\underline{2}$
(1- Paved, 2- Not paved)

10. Embankment slope (run / rise in feet / foot):

US left 47.6:1

\begin{tabular}{|c|c|c|c|}
\hline \multicolumn{2}{|c|}{ Protection } & \multirow{2}{*}{ 13. Erosion } & \multirow{2}{*}{ 14.Severity } \\
\hline 11.Type & 12. Cond. & & \\
\hline 1 & & 2 & 1 \\
\hline
\end{tabular}

LBUS

RBUS

RBDS

LBDS

\begin{tabular}{l|l}
\hline 1 & 1 \\
\hline 1 & 1 \\
\hline 0 & - \\
\hline
\end{tabular}

\begin{tabular}{l|l}
$\frac{1}{0}$ & - \\
\hline 0 & - \\
\hline 2 & 1 \\
\hline
\end{tabular}

Bank protection types: 0 - none; 1- $<12$ inches;

2- $<36$ inches; 3- $<48$ inches;

4- < 60 inches; 5- wall / artificial levee

Bank protection conditions: 1- good; 2- slumped;

3- eroded; 4- failed

Erosion: 0 - none; 1- channel erosion; 2 -

road wash; 3- both; 4- other

Erosion Severity: 0 - none; 1- slight; 2- moderate; 3- severe

\section{Channel approach to bridge (BF):}

15. Angle of approach: 15

16. Bridge skew: 15

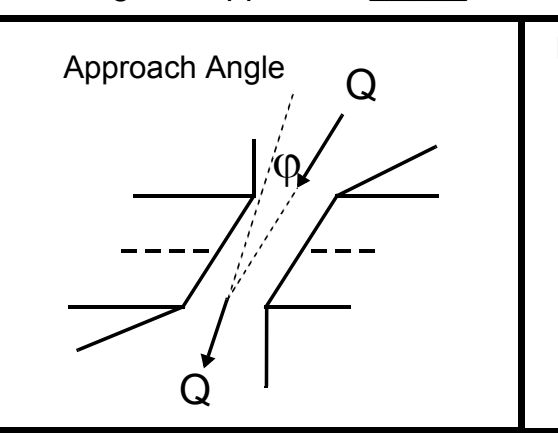

17. Channel impact zone 1 :

Where? LB (LB, RB)

Range? 28

feet US

Channel impact zone 2:

Where? RB (LB, RB) Bridge Skew Angle

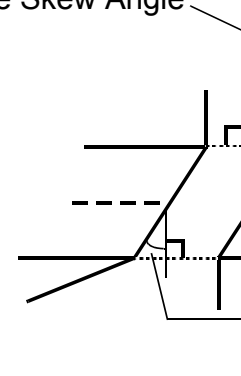

\section{Exist? $\mathbf{Y}(Y$ or $N)$}

Severity 2

$U B, D S)$ to 8 feet US

Opening skew to roadway

$\alpha=\mathbf{0 . 0}$ 
18. Bridge Type: $\mathbf{1 b}$

1a- Vertical abutments with wingwalls

$1 \mathrm{~b}$ - Vertical abutments without wingwalls

2- Vertical abutments and wingwalls, sloping embankment Wingwalls parallel to abut. face

3- Spill through abutments

4- Sloping embankment, vertical wingwalls and abutments

Wingwall angle less than $90^{\circ}$.

19. Bridge Deck Comments (surface cover variations, measured bridge and span lengths, bridge type variations, approach overflow width, etc.)

\#4: The LBUS, RBUS, and LBDS are very low and marshy areas where pasture fields exist beyond. The RBDS is vegetated with shrubs and trees; a quarried wall of bedrock is beyond the brushland.

\#7: Measured bridge length $=31.6$ feet; bridge span $=29$ feet; bridge width $=24.7$ feet .

\#11: The upstream bank protection also acts as road embankment protection.

\section{Upstream Channel Assessment}

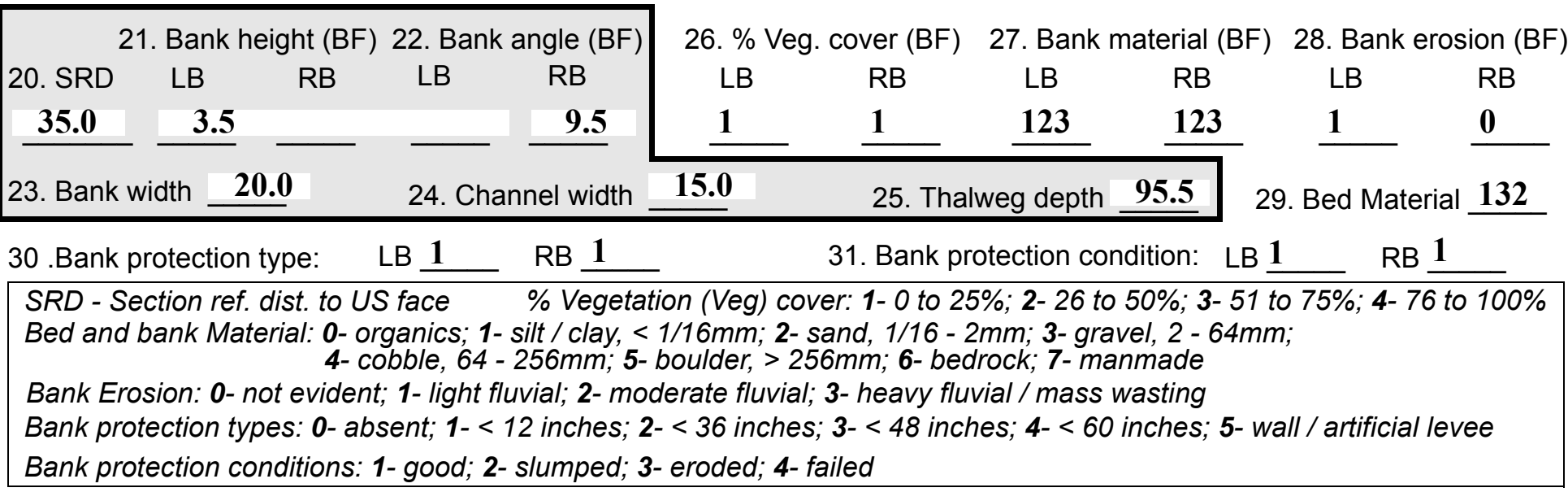

32. Comments (bank material variation, minor inflows, protection extent, etc.):

\#28: The stream makes a sharp bend before the bridge.

\#30: Bank protection on the left bank extends 30 feet upstream.

Bank protection on right bank extends 36 feet upstream. 
33.Point/Side bar present? $\mathbf{N}(Y$ or $N$. if $N$ type ctrl-n pb)34. Mid-bar distance: -

35. Mid-bar width:

36. Point bar extent: feet (US, UB) to feet (US, UB, DS) positioned $\%$ LB to $\% \mathrm{RB}$

37. Material:

38. Point or side bar comments (Circle Point or Side; Note additional bars, material variation, status, etc.):

NO POINT BARS

39. Is a cut-bank present? $\underline{\mathbf{N}}$ (Y or if $\mathrm{N}$ type ctrl-n cb)

40. Where? (LB or $R B)$

41. Mid-bank distance: -

42. Cut bank extent: feet (US, UB) to feet (US, UB, DS)

43. Bank damage: (1- eroded and/or creep; 2- slip failure; 3- block failure)

44. Cut bank comments (eg. additional cut banks, protection condition, etc.):

NO CUT BANKS

\section{Is channel scour present? $\mathbf{Y}$ ( $Y$ or if $N$ type ctrl-n cs) $\quad$ 46. Mid-scour distance: $\mathbf{3 4}$ US}

47. Scour dimensions: Length $\underline{8}$ Width $\underline{\mathbf{2}}$ Depth : $\underline{\mathbf{0 . 5}}$ Position $\underline{\mathbf{5}} \%$ LB to $\underline{\mathbf{1 5}}$ \%RB

48. Scour comments (eg. additional scour areas, local scouring process, etc.):

Channel scour is present where the stream bends.

\section{Are there major confluences? $\mathbf{N}$}

51. Confluence 1: Distance Confluence 2: Distance 52. Enters on Enters on 4. Confluence comments (eg. confluence name):

\section{NO MAJOR CONFLUENCES}

50. How many? -

53. Type(1-perennial; 2- ephemeral)

Type (1-perennial; 2-ephemeral)

\section{Under Bridge Channel Assessment}

55. Channel restraint (BF)? LB 2

\begin{tabular}{|ccccc}
\hline \multicolumn{2}{|c}{ 56. Height (BF) } & \multicolumn{3}{c}{57 Angle (BF) } \\
LB & RB & LB & RB \\
$\mathbf{5 1 . 5}$ & & & $\mathbf{3 . 5}$ & \\
\hline
\end{tabular}
(1- natural bank; 2- abutment; 3- artificial levee)

58. Bank width (BF) -

59. Channel width =

61. Material (BF)

LB RB

$\underline{2} \quad 7$
62. Erosion (BF)

LB RB 7

Bed and bank Material: 0- organics; 1- silt / clay, < 1/16mm; 2- sand, 1/16 - 2mm; 3- gravel, 2 - 64mm; 4- cobble, 64 - 256mm; 5- boulder, > 256mm; 6- bedrock; 7- manmade

Bank Erosion: 0- not evident; 1- light fluvial; 2- moderate fluvial; 3- heavy fluvial / mass wasting

64. Comments (bank material variation, minor inflows, protection extent, etc.): 41

The bed material under the bridge is mostly stone fill. 
65. Debris and Ice Is there debris accumulation?

(Yor $N)$ 66. Where? $\mathbf{N}$

(1- Upstream; 2- At bridge; 3-Both)

67. Debris Potential ( 1- Low; 2- Moderate; 3- High)

68. Capture Efficiency 1 (1-Low; 2- Moderate; 3- High)

69. Is there evidence of ice build-up? 2 (Y or $N)$

Ice Blockage Potential $\mathbf{N}$ (1- Low; 2- Moderate; 3- High)

70. Debris and Ice Comments:

2

\#68: Capture efficiency is moderate because of low bridge clearance.

\#69: Ice blockage potential is moderate because of low bridge clearance.

\begin{tabular}{|l|c|c|c|c|c|c|c|c|}
\hline Abutments & $\begin{array}{c}\text { 71. Attack } \\
\angle \text { (BF) }\end{array}$ & $\begin{array}{c}\text { 72. Slope } \angle \\
\text { (Qmax) }\end{array}$ & $\begin{array}{c}\text { 73. Toe } \\
\text { loc. (BF) }\end{array}$ & $\begin{array}{c}\text { 74. Scour } \\
\text { Condition }\end{array}$ & $\begin{array}{c}\text { 75. Scour } \\
\text { depth }\end{array}$ & $\begin{array}{c}\text { 76. Exposure } \\
\text { depth }\end{array}$ & 77. Material & 78. Length \\
\hline LABUT & & - & $\mathbf{8 0}$ & $\mathbf{2}$ & $\mathbf{0}$ & - & - & $\mathbf{9 0 . 0}$ \\
\hline RABUT & $\mathbf{1}$ & $\mathbf{1 0}$ & $\mathbf{8 0}$ & & & $\mathbf{2}$ & $\mathbf{0}$ & $\mathbf{2 5 . 0}$ \\
\hline
\end{tabular}

Pushed: $L B$ or RB

Toe Location (Loc.): 0- even, 1- set back, 2- protrudes

Scour cond.: 0- not evident; 1- evident (comment); 2- footing exposed; 3-undermined footing; 4- piling exposed; 5- settled; 6- failed

Materials: 1- Concrete; 2- Stone masonry or drywall; 3- steel or metal; 4- wood

79. Abutment comments (eg. undermined penetration, unusual scour processes, debris, etc.):

-

1

The concrete abutment walls are at a slight angle. The protection dumped in front of the abutments is at about a 60 degree slope angle and it extends about six feet from the front of the concrete abutments.

80. Wingwalls:

Exist? Material? Scour Scour Exposure 81. Condition? depth? depth?

USLWW:

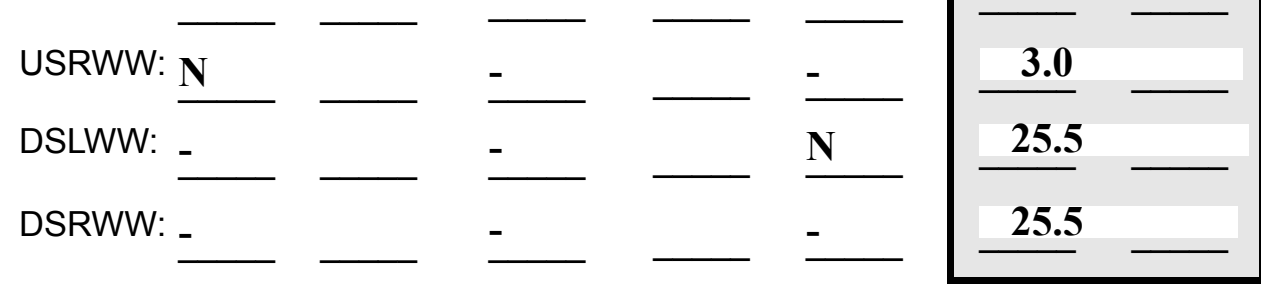

Wingwall materials: 1- Concrete; 2- Stone masonry or drywall; 3- steel or metal; 4- wood

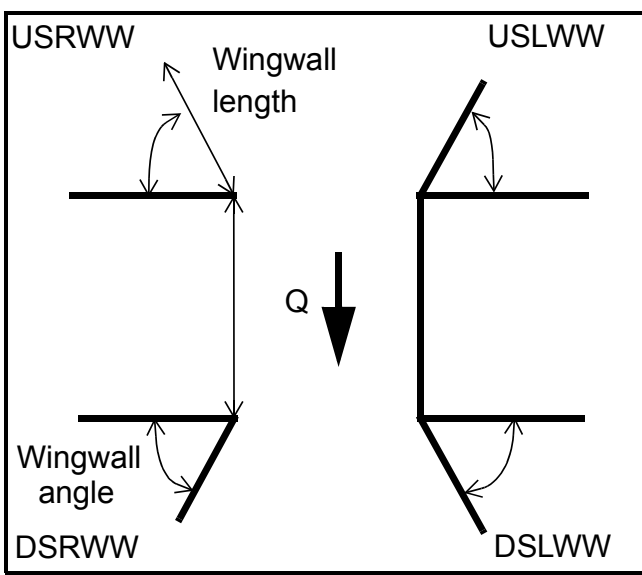

82. Bank / Bridge Protection:

\begin{tabular}{|l|l|l|l|l|l|l|l|c|}
\hline Location & USLWW & USRWW & LABUT & RABUT & LB & RB & DSLWW & DSRWW \\
\hline Type & - & - & N & - & - & - & $\mathbf{1}$ & $\mathbf{1}$ \\
\hline Condition & $\mathbf{N}$ & - & - & - & - & - & $\mathbf{1}$ & $\mathbf{1}$ \\
\hline Extent & - & - & - & - & - & $\mathbf{1}$ & $\mathbf{1}$ & - \\
\hline
\end{tabular}

Bank / Bridge protection types: 0- absent; 1- < 12 inches; 2- < 36 inches; 3- < 48 inches; 4- < 60 inches; 
83. Wingwall and protection comments (eg. undermined penetration, unusual scour processes, etc.):

-
-
-
-
-
-
-
-

\section{Piers:}

84. Are there piers? (Y or if $N$ type ctrl-n pr)

\begin{tabular}{|l|l|l|l|l|l|l|l|}
\hline \multirow{2}{*}{$\begin{array}{l}85 . \\
\text { Pier no. }\end{array}$} & \multicolumn{3}{|c|}{ width (w) feet } & \multicolumn{3}{c|}{ elevation (e) feet } \\
\cline { 2 - 9 } & w1 & w2 & w3 & e@w1 & e@w2 & e@w3 \\
\hline Pier 1 & - & - & - & - & - & - \\
\hline Pier 2 & - & - & - & - & - & - \\
\hline Pier 3 & - & - & - & - & - & - \\
\hline Pier 4 & - & - & - & - & - & - \\
\hline
\end{tabular}

\begin{tabular}{|l|l|l|l|l|}
\hline Level 1 Pier Descr. & 1 & \multicolumn{1}{|c|}{2} & 3 & \multicolumn{1}{|c|}{} \\
\hline 86. Location (BF) & & - & - & - \\
\hline 87. Type & & - & - & - \\
\hline 88. Material & & - & - & - \\
\hline 89. Shape & & - & - & - \\
\hline 90. Inclined? & & - & - & - \\
\hline 91. Attack $\angle$ (BF) & & - & - & - \\
\hline 92. Pushed & & - & - & - \\
\hline 93. Length (feet) & - & - & - & - \\
\hline 94. \# of piles & & - & - & - \\
\hline 95. Cross-members & & - & - & - \\
\hline 96. Scour Condition & & - & - & - \\
\hline 97. Scour depth & $\mathbf{N}$ & - & - & - \\
\hline 98. Exposure depth & - & - & - & - \\
\hline
\end{tabular}

LFP, LTB, LB, MCL, MCM, MCR, RB, RTB, RFP

1- Solid pier, 2- column, 3- bent

1-Wood; 2- concrete; 3- metal; 4- stone

1- Round; 2- Square; 3- Pointed

Y-yes; $N$ - no

$L B$ or $R B$

0- none; 1- laterals; 2- diagonals; 3- both

0- not evident; 1- evident (comment);

2- footing exposed; 3- piling exposed;

4- undermined footing; 5- settled; 6- failed 
99. Pier comments (eg. undermined penetration, protection and protection extent, unusual scour processes, etc.):

-
-
-
-
-
-
-
-
-
-

100.

\section{E. Downstream Channel Assessment}

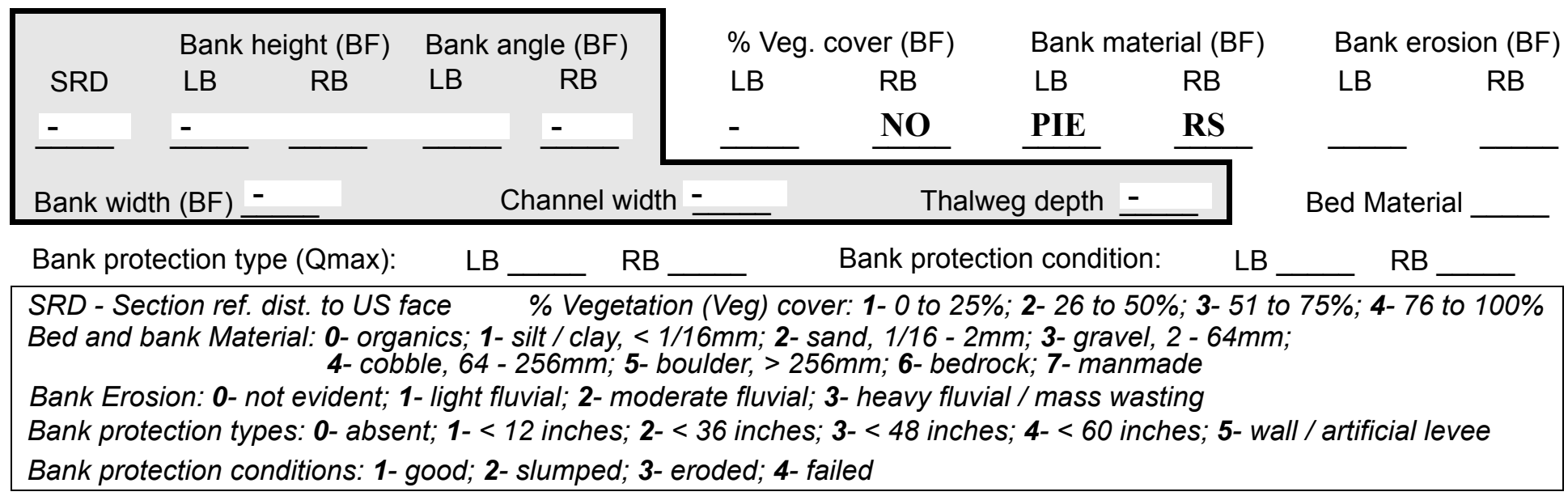

Comments (eg. bank material variation, minor inflows, protection extent, etc.):

1

1

12

123

0

1

14

0

2

1

Right bank protection extends from 4 feet US to 75 feet DS. There is a break in the protection where the DS cut-bank exists from 20 feet DS to 30 feet DS.

101. Is a drop structure present? Bo ( $Y$ or $N$, if $N$ type ctrl-n ds) 102. Distance: ___ feet

103. Drop: -_ feet 104. Structure material: th (1- steel sheet pile; 2- wood pile; 3- concrete; 4- other)

105. Drop structure comments (eg. downstream scour depth):

banks have type 1 protection, which extends from the DS bridge face to 4 feet DS. 
106. Point/Side bar present? (Y or $N$. if $N$ type ctrl-n pb)Mid-bar distance:

Mid-bar width:

Point bar extent: feet

(US, UB, DS) to feet (US, UB, DS) positioned $\underline{\mathbf{N}}$ $\%$ LB to $\% R B$

Material: $\mathbf{N O}$

Point or side bar comments (Circle Point or Side; note additional bars, material variation, status, etc.):

\section{DROP STRUCTURE}

Is a cut-bank present? (Y or if $N$ type ctrl-n cb) Where? $(L B$ or $R B)$

Mid-bank distance: $\mathbf{Y}$

Cut bank extent: $\underline{\mathbf{7 0}}$ feet $\underline{\mathrm{DS}}$ (US, UB, DS) to $\underline{4}$ feet $\underline{\mathbf{6 0}}$ (US, UB, DS)

Bank damage: DS (1- eroded and/or creep; 2- slip failure; 3- block failure)

Cut bank comments (eg. additional cut banks, protection condition, etc.):

75

DS

20

30

$\underline{\text { Is channel scour present? }} \mathbf{1 0}$ (Y or if $N$ type ctrl-n cs) Mid-scour distance: This Scour dimensions: Length chan Width nel Depth: bar Positioned is \% Scour comments (eg. additional scour areas, local scouring process, etc.): ered with grass.

Are there major confluences? $\mathbf{Y}$ ( $Y$ or if $N$ type ctrl-n $m c)$

Confluence 1: Distance $\mathbf{3 0}$

Confluence 2: Distance DS Enters on $\underline{\mathbf{D S}}(L B$ or $R B)$

Enters on $\mathbf{3 2}$ (LB or $R B)$
How many? RB

Type 20 (1- perennial; 2- ephemeral)

Type DS (1-perennial; 2- ephemeral)

Confluence comments (eg. confluence name):

1

Very slight damage from eddying.

\section{F. Geomorphic Channel Assessment}

107. Stage of reach evolution

1- Constructed

2- Stable

3- Aggraded

4- Degraded

5- Laterally unstable

6- Vertically and laterally unstable 
108. Evolution comments (Channel evolution not considering bridge effects; See HEC-20, Figure 1 for geomorphic descriptors):

$\mathbf{N}$

$-$

$-$

$-$

$-$

$-$

-

NO CHANNEL SCOUR 


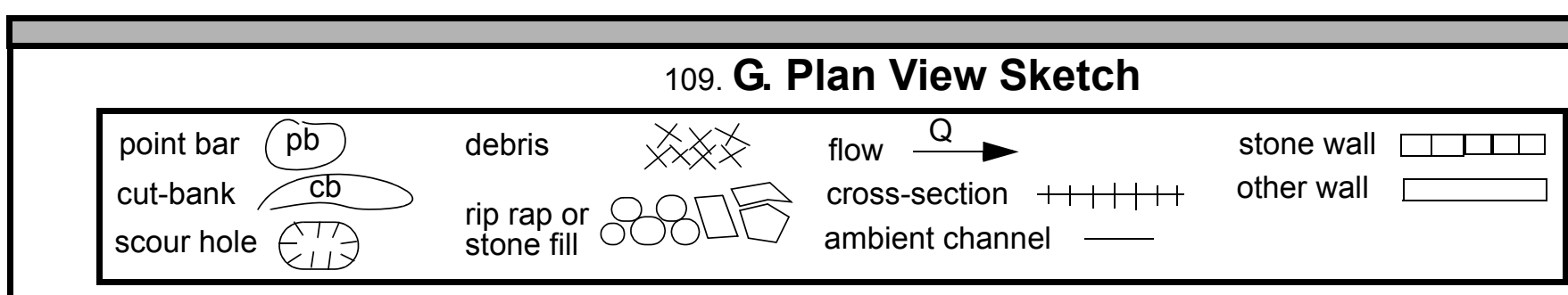


APPENDIX F:

SCOUR COMPUTATIONS 
SCOUR COMPUTATIONS

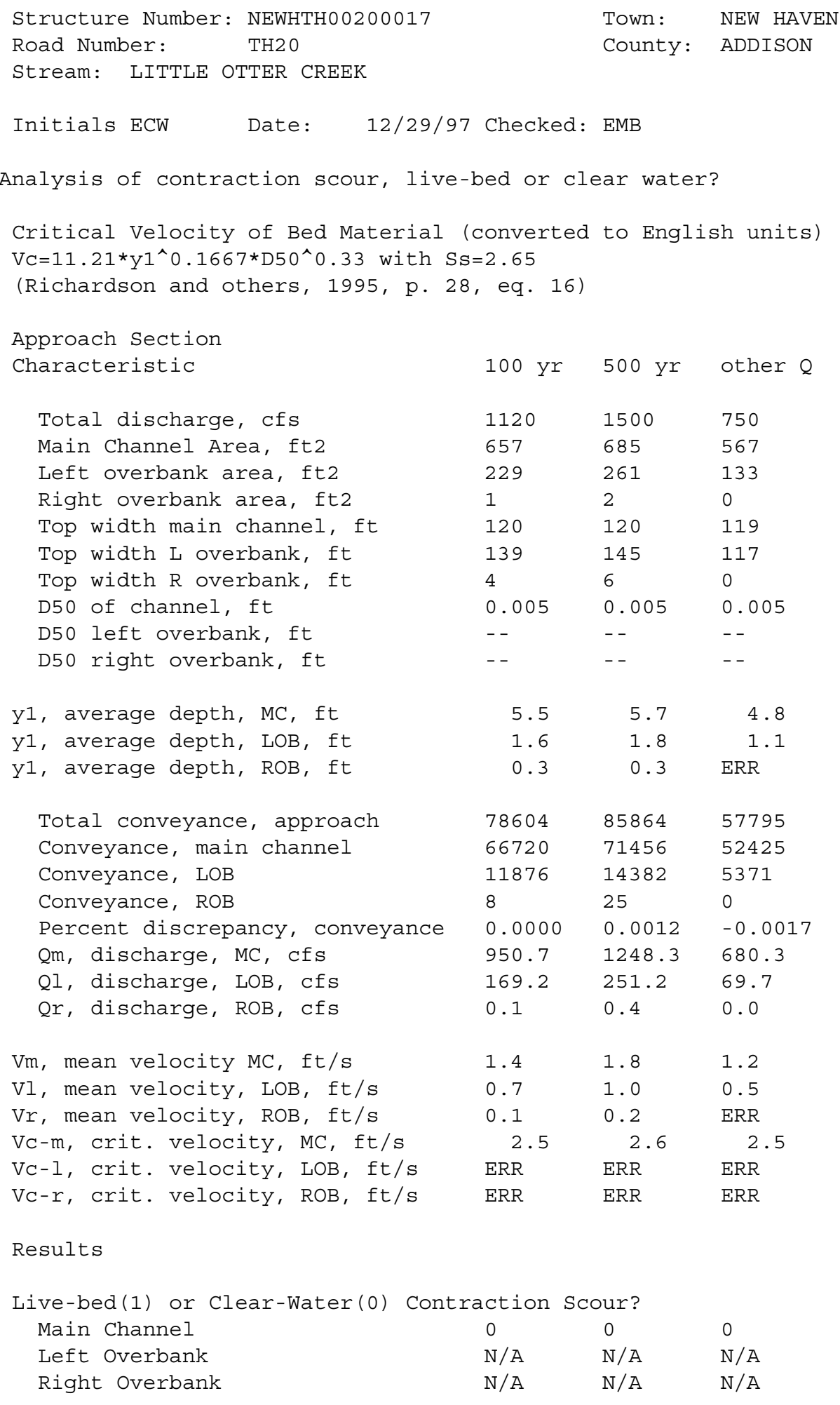


Clear water Contraction Scour in MAIN CHANNEL

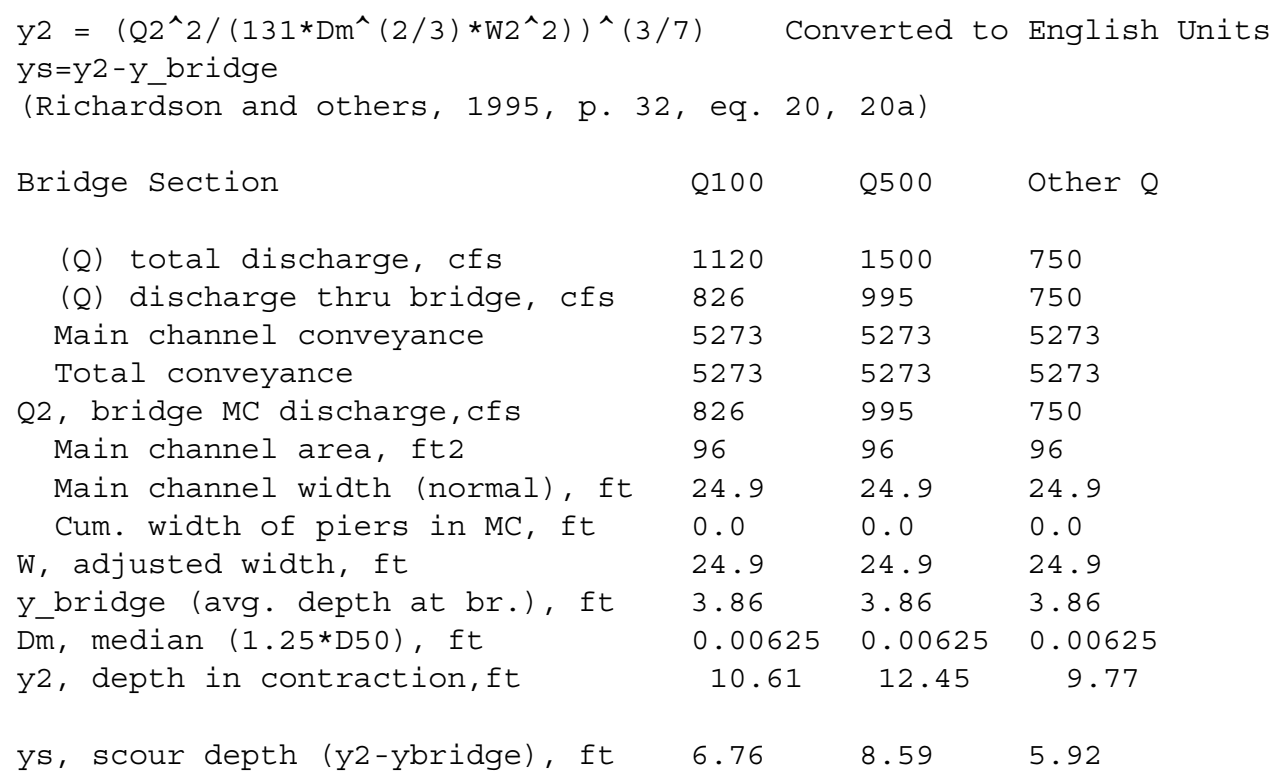

Armoring

$\mathrm{DC}=\left[\left(1.94 * \mathrm{~V}^{\wedge} 2\right) /(5.75 * \log (12.27 * \mathrm{Y} / \mathrm{D} 90))^{\wedge} 2\right] /[0.03 *(165-62.4)]$

Depth to Armoring $=3 *(1 / \mathrm{PC}-1)$

(Federal Highway Administration, 1993)

Downstream bridge face property 100-yr 500-yr Other Q

Q, discharge thru bridge MC, Cfs $826 \quad 995 \quad 750$

Main channel area (DS), ft2 $\quad 92 \quad 96 \quad 78$

Main channel width (normal), ft $24.9 \quad 24.9 \quad 24.9$

Cum. width of piers, ft $\quad 0.0 \quad 0.0 \quad 0.0$

Adj. main channel width, ft $\quad 24.9 \quad 24.9 \quad 24.9$

$\begin{array}{llll}\text { D90, ft } & 0.4790 & 0.4790 & 0.4790\end{array}$

$\begin{array}{llll}\text { D95, ft } & 0.6525 & 0.6525 & 0.6525\end{array}$

$\begin{array}{lllll}\text { Dc, critical grain size, ft } & 0.3935 & 0.5148 & 0.4860\end{array}$

PC, Decimal percent coarser than DC $0.211 \quad 0.086 \quad 0.971$

$\begin{array}{llll}\text { Depth to armoring, ft } & 4.43 & 16.50 & 0.04\end{array}$ 


\begin{tabular}{|c|c|c|c|c|}
\hline $\begin{array}{l}\text { Chang pressure flow equation } \\
\mathrm{Cq}=1 / \mathrm{Cf} * \mathrm{Cc} \quad \mathrm{Cf}=1.5 * \mathrm{Fr}^{\wedge} 0.43(<=1) \\
\text { Umbrell pressure flow equation } \\
\text { (Hb+Ys)/ya=1.1021*[(1-w/ya)*(Va/VC) } \\
\text { (Richardson and other, 1995, p. } 144\end{array}$ & $\begin{array}{l}\mathrm{Hb}+\mathrm{Ys}=\mathrm{Cq} \\
\mathrm{CC}=\mathrm{SQRT} \\
]^{\wedge} 0.6031 \\
-146)\end{array}$ & $\begin{array}{l}\text { * qbr/Vc } \\
0.10(\mathrm{Hb} /\end{array}$ & $(y a-w)-0.56)]+0.79$ & $(<=1)$ \\
\hline & Q100 & Q500 & OtherQ & \\
\hline Q, total, cfs & 1120 & 1500 & 750 & \\
\hline Q, thru bridge $\mathrm{MC}$, cfs & 826 & 995 & 750 & \\
\hline Vc, critical velocity, ft/s & 2.54 & 2.56 & 2.49 & \\
\hline Va, velocity MC approach, ft/s & 1.45 & 1.82 & 1.20 & \\
\hline Main channel width (normal), ft & 24.9 & 24.9 & 24.9 & \\
\hline Cum. width of piers in MC, ft & 0.0 & 0.0 & 0.0 & \\
\hline W, adjusted width, ft & 24.9 & 24.9 & 24.9 & \\
\hline qbr, unit discharge, ft2/s & 33.2 & 40.0 & 30.1 & \\
\hline Area of full opening, ft2 & 96.0 & 96.0 & 96.0 & \\
\hline $\mathrm{Hb}$, depth of full opening, ft & 3.86 & 3.86 & 3.86 & \\
\hline Fr, Froude number, bridge $\mathrm{MC}$ & 0.77 & 0.93 & 0.7 & \\
\hline Cf, Fr correction factor $(<=1.0)$ & 1.00 & 1.00 & 1.00 & \\
\hline **Area at downstream face, ft2 & 92 & $\mathrm{~N} / \mathrm{A}$ & 78 & \\
\hline$* * \mathrm{Hb}$, depth at downstream face, ft & 3.69 & $\mathrm{~N} / \mathrm{A}$ & 3.13 & \\
\hline$\star *$ Fr, Froude number at DS face & 0.82 & ERR & 0.96 & \\
\hline$* * C f$, for downstream face $(<=1.0)$ & 1.00 & $\mathrm{~N} / \mathrm{A}$ & 1.00 & \\
\hline Elevation of Low steel, ft & 497.67 & 497.67 & 497.67 & \\
\hline Elevation of Bed, ft & 493.81 & 493.81 & 493.81 & \\
\hline Elevation of Approach, ft & 500.41 & 500.64 & 499.66 & \\
\hline Friction loss, approach, ft & 0.08 & 0.11 & 0.06 & \\
\hline Elevation of WS immediately US, ft & 500.33 & 500.53 & 499.60 & \\
\hline ya, depth immediately US, ft & 6.52 & 6.72 & 5.79 & \\
\hline Mean elevation of deck, ft & 499.8 & 499.8 & 499.8 & \\
\hline w, depth of overflow, ft $(>=0)$ & 0.53 & 0.73 & 0.00 & \\
\hline Cc, vert contrac correction $(<=1.0)$ & 0.88 & 0.88 & 0.89 & \\
\hline$* * C c$, for downstream face $(<=1.0)$ & 0.865694 & ERR & 0.79 & \\
\hline Ys, scour w/Chang equation, ft & 10.93 & 13.83 & 9.71 & \\
\hline Ys, scour w/Umbrell equation, ft & 1.00 & 1.77 & 0.25 & \\
\hline
\end{tabular}




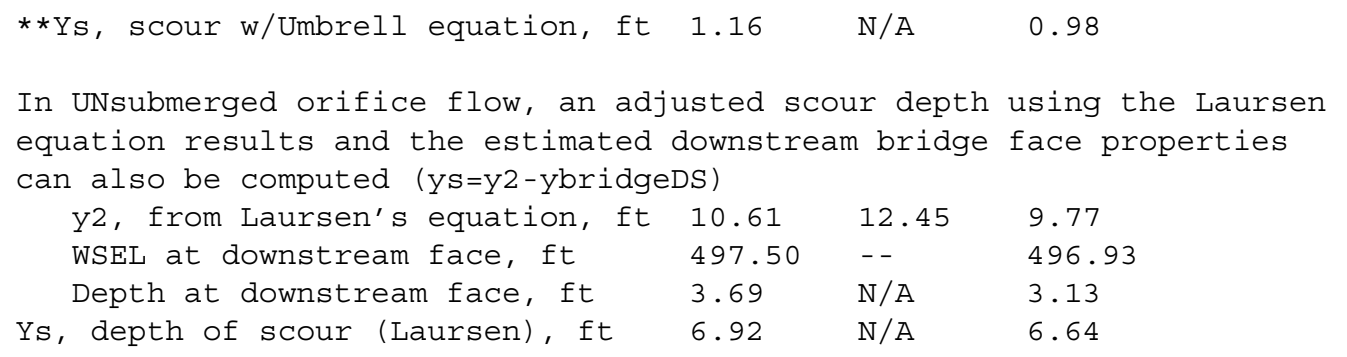

Abutment Scour

Froehlich's Abutment Scour

$\mathrm{Ys} / \mathrm{Y} 1=2.27 * \mathrm{~K} 1 * \mathrm{~K} 2 *\left(\mathrm{a}^{\prime} / \mathrm{Y} 1\right)^{\wedge} 0.43 * \mathrm{Fr} 1^{\wedge} 0.61+1$

(Richardson and others, 1995, p. 48, eq. 28)

Characteristic

Left Abutment Right Abutment 100 yr Q 500 yr Q Other Q 100 yr Q 500 yr Q Other Q

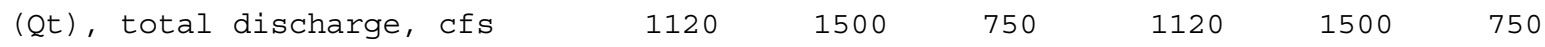

$\begin{array}{llllllll}\mathrm{a}^{\prime} \text {, abut.length blocking flow, ft } & 205.5 & 212.2 & 183.8 & 32.1 & 34 & 27.7\end{array}$

$\begin{array}{lllllll}\mathrm{Ae}, \text { area of blocked flow ft2 } & 434.54 & 446.13 & 372.6 & 149.43 & 150.58 & 135.58\end{array}$

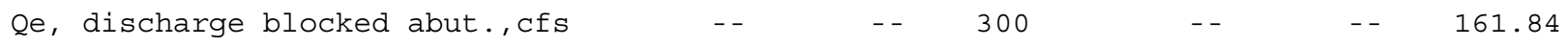

(If using Qtotal_overbank to obtain Ve, leave Qe blank and enter Ve and Fr manually)

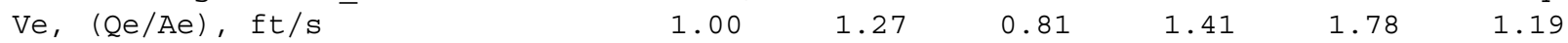

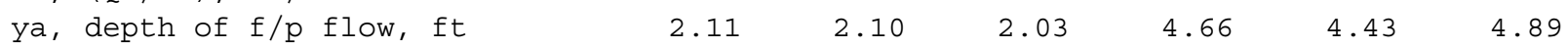

--Coeff., K1, for abut. type (1.0, verti.; 0.82, verti. w/ wingwall; 0.55, spillthru)

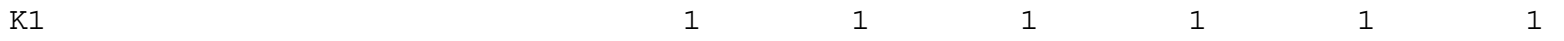

--Angle (theta) of embankment (<90 if abut. points DS; >90 if abut. points US)

$\begin{array}{lllllll}\text { theta } & 90 & 90 & 90 & 90 & 90 & 90\end{array}$

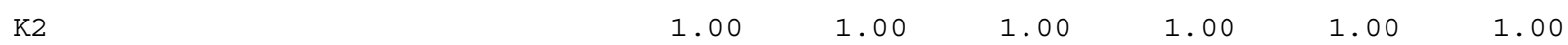

Fr, froude number f/p flow $\quad \begin{array}{llllll}0.111 & 0.137 & 0.100 & 0.113 & 0.142 & 0.095\end{array}$

$\begin{array}{lllllll}\text { ys, scour depth, ft } & 11.10 & 12.43 & 9.86 & 11.07 & 11.77 & 10.47\end{array}$

HIRE equation (a'/ya > 25)

$\mathrm{Ys}=4 * \mathrm{Fr}^{\wedge} 0.33 * \mathrm{Y} 1 * \mathrm{~K} / 0.55$

(Richardson and others, 1995, p. 49, eq. 29) 


\begin{tabular}{|c|c|c|c|c|c|c|}
\hline$a^{\prime}$ (abut length blocked, ft) & 205.5 & 212.2 & 183.8 & 32.1 & 34 & 27.7 \\
\hline y1 (depth f/p flow, ft) & 2.11 & 2.10 & 2.03 & 4.66 & 4.43 & 4.89 \\
\hline$a^{\prime} / y 1$ & 97.18 & 100.93 & 90.67 & 6.90 & 7.68 & 5.66 \\
\hline Skew correction (p. 49, fig. 16) & 1.00 & 1.00 & 1.00 & 1.00 & 1.00 & 1.00 \\
\hline Froude no. f/p flow & 0.11 & 0.14 & 0.10 & 0.11 & 0.14 & 0.10 \\
\hline $\begin{array}{c}\text { Ys w/ corr. factor K1/0.55: } \\
\text { vertical }\end{array}$ & 7.45 & 7.93 & 6.89 & ERR & ERR & ERR \\
\hline vertical w/ ww's & 6.10 & 6.51 & 5.65 & ERR & ERR & ERR \\
\hline spill-through & 4.09 & 4.36 & 3.79 & ERR & ERR & ERR \\
\hline Abutment riprap Sizing & & & & & & \\
\hline Isbash Relationship & & & & & & \\
\hline $\mathrm{D} 50=\mathrm{Y} * \mathrm{~K} * \mathrm{Fr}{ }^{\wedge} 2 /(\mathrm{Ss}-1)$ and $\mathrm{D} 50=\mathrm{Y} * \mathrm{~K} *$ & $\wedge 21 \wedge 0.1$ & $(S s-1)$ & & & & \\
\hline (Richardson and others, 1995, p11 & eq. 81 & & & & & \\
\hline Characteristic & Q100 & 2500 & Other $Q$ & Q100 & Q500 & Other $Q$ \\
\hline Fr, Froude Number & 0.82 & 0.93 & 0.96 & 0.82 & 0.93 & 0.96 \\
\hline$y$, depth of flow in bridge, ft & 3.69 & 3.86 & 3.13 & 3.69 & 3.86 & 3.13 \\
\hline Median Stone Diameter for riprap & : left & atment & & right & abutment, & ft \\
\hline Fr $<=0.8$ (vertical abut.) & ERR & ERR & ERR & $E R R$ & ERR & ERR \\
\hline Fr>0.8 (vertical abut.) & 1.46 & 1.58 & 1.29 & 1.46 & 1.58 & 1.29 \\
\hline
\end{tabular}

